\title{
How Compassion and Justice Mediate the effect of Ethical Leadership on Interpersonal Citizenship Behavior (OCBI)
}

\author{
Fakeha Anwer \\ Research Scholar \\ Karachi University Business School, University of Karachi, Pakistan \\ E-mail: fakehaanwer20@gmail.com \\ Dr. Danish Ahmed Siddiqui \\ Associate Professor \\ Karachi University Business School, University of Karachi, Pakistan \\ E-mail: daanish79@ hotmail.com
}

Received: October 6, 2021 Accepted: November 5, 2021 Published: November 10, 2021

doi:10.5296/gjes.v7i2.19171 URL: https://doi.org/10.5296/gjes.v7i2.19171

\begin{abstract}
While many analysts have directed few investigations on the influence of ethical leadership on the behavior of citizenship, in different contexts, however, not much is known about the moral components make it possible to produce follow-up findings as Organizational Citizenship Behavior(OCBs) for leaders, especially, Interpersonal OCBs (OCBI). For this, we suggested a hypothetical structure, thereby adapting Zoghbi-Manrique-de-Lara and Viera-Armas (2019) model to include Organizational Justice. Therefore, we intend to study the association of Ethical Leadership with OCBI empirically while in the view of various determining factors of Workplace Compassion (i.e. empathic concern, common humanity, mindfulness, and kindness), and Organizational Justice (i.e. procedural justice, distributive justice, and interactional justice) as mediating variables. Empirical validity was recognized; by directing a review utilizing a standardized close-ended questionnaire. Using Confirmatory
\end{abstract}




\section{Macrothink}

Global Journal of Educational Studies

ISSN 2377-3936

2021, Vol. 7, No. 2

Factor Analysis (CFA) and Structured Equation Modeling (SEM), information was collected from 350 employees and investigated. Both direct and indirect effect was tested; by using Structural Equation Modeling (SEM) via SmartPLS software. Thus, the results revealed that: except for Common Humanity, ethical leadership remained significantly and positively connected with all factors of Workplace Compassion (Empathic Concern, Mindfulness, and Kindness), as well as with all three-factor of Organizational Justice (Procedural Justice, Distributive Justice, and Interactional Justice. However, ethical leadership seems to hurt the Mindfulness factor. Also, among compassion determinants, only Empathic Concern seems to affect OCBI. Whereas only interactional justice has a significant positive association with OCBI; further, the findings revealed that there is an insignificant mediating effect of workplace compassion and organizational justice in the ethical leadership relationship with OCBI. Hence, the investigation has portrayed significant ramifications for the organizations.

Keywords: Ethical Leadership, Interpersonal Citizenship Behavior (OCBI), Workplace Compassion, Organizational Justice, Structural Equation Modeling (SEM), SmartPLS 


\section{Introduction}

\subsection{Background to the Study}

The organization's success is one of essential responsibility on the heads of the organization since leadership is an ethical practice (Ciulla, 1995; Yukl, 2002). The objectives of the organizations are mostly reliant on the skills and abilities of leaders which enables organizational individuals, advance by better implementation in the context of those objectives. Ethical leadership can incorporate a management approach which can explore concerns of improved outcomes of an employee (Brown \& Mitchell, 2010; Brown \& Treviño, 2006a; Dadhich \& Bhal, 2008; Mayer et al., 2009).

Moral leadership has recently been considered an important issue that influences the attitude and behavior of employees in administrations (Mo et al., 2012). It puts a lot of accentuation on the imitative model of the behavior of leaders in the working environment (Treviño et al., 2000, 2003; Brown, 2007). In the region of the administration and social ethics in the associations, the ethical behavior of leaders is considered one of the most appropriate variables in the workplace to influence the moral performance of their followers (e.g., Bies and Moag (1986); Brown and Treviño (2006)). As leadership comprises a social process in groups. To gain a sense of social learning, past examination suggests that workers employed with behavioral managers can attend "more and more" formal calls to assist associations with accomplishing objectives for long-term targets (Podsakoff et al., 1997, 2000; Piccolo et al., 2010; Kalshoven et al., 2011; Zoghbi-Manriquede-Lara \& Suarez-Acosta, 2013; Boehm \& Dwertmann, 2015).

In comprehensive research on leadership ethics, Northouse (2010) explained morals as vital to administrations indicating the effect of leader impact, connection with individuals, and the formation of administrative standards. Dadhich and Bhal (2008) stated that ethical leadership can impact on work-related behavior and execution. Empirical research is a fairly new yet developing area in linking between ethical leadership and employee approaches or etiquettes (Trevino et al., 2003; Mayer, Kuenzi, Greenbaum, Bardes, \& Salvador, 2009; Rubin, Dierdorff \& Brown, 2010).

However, little is identified about the basic practices by which physical leadership improves the effectiveness of the organization of workers (Brown \& Treviño, 2006; Kirkman et al., 2009). Furthermore, Brown and Treviño (2014) also discovered that his subordinate-appraised moral leadership was extremely affected if the leader had a good example in his work. This influence was controlled by the era of an ethical leader in which old leaders noted a strong connection between vocational mentoring and ethical leadership. The age of the leader dominated the relationship between youthful models and assessment of ethical leadership.

Organizational Citizenship Behaviors (OCBs) are versatile individual activities that executives exceptionally consider as they can enhance the productivity of the company (Organ, 1988). Such helping forms may either be administratively based on systems, such as defending the company while others examine it or personally based on processes, such as 
having criteria to facilitate the prosperity of peers. The Organizational Citizenship Behaviors $(\mathrm{OCBs})$ are morally obligatory actions significantly violate ethical standards and are mostly not effortlessly tolerated in work. Since such Organizational Citizenship Behaviors cannot be applied in the work and workers may explicitly refuse to engage in them, previous analysis indicates that leaders use fundamentally roused methods to encourage them (Kuvaas \& Dysvik, 2009; Piccolo \& Colquitt, 2006). The previously mentioned lack of study of the underlying moral frameworks between the behavior of leaders and the OCBs of followers seems to be most significant in the socially mediated responses to ethical leadership because leadership needs social practices in meetings.

Observing if moral components underlie the impact of moral leaders on peer-focused OCBs can deliver better approaches for organizations to promote the quality of workplace relationships and, possibly, the functioning of a superior work environment. As Weaver et al. (1999:55), observed, "In organizations, executive commitment towards morality has serious ethical governance problems, and leaders should honestly understand their role." Positive Organizational Ethics (POEs), (Stansbury \& Sonenshein, 2012), is a technique that transfers the emphasis from procedures and discipline towards principles that encourage individuals while taking part in such deviance in a fundamental ethical manner.

Positive Organizational Ethics (POEs) emphasize on ethics as an affirmative activity or living- code (Verbos et al., 2007) that overtakes laws (Sekerka, 2010) and contributes to the highest moral capacity of organizations (Handelsman et al., 2009).

One of the channel through which ethical leaders exerts their influence is through compassion. Compassion in a workplace could run from an individual demonstration to a collective and sorted out the act. Individual or dyadic compassion in the work environment is introduced when an individual communicates his/her coworker's concerns, feels compassion, and makes a move to support him/her. Likewise, it can take an aggregate structure when a group of coworkers gets engaged in a compassionate demonstration. Kanov et al. (2004) stated this as "Organizational Compassion" which creates with an individual observing a coworker's problem, however, turns into a social manner with a group of coworkers recognizing the presence of agony and feel moved to take action in an aggregate manner. It can be a valuable manner for the organization. According to Rinpoche (1992), "Compassion is not just a feeling of sympathy or concern for someone's suffering, not just warmth of heart toward somebody before you, or a sharp acknowledgment need of their needs and agony. Moreover, it is a supported and practical determination to do whatever is conceivable and essential to assist with decreasing their suffering".

The above-mentioned concept of compassion advises that compassion assessment is an intricate procedure. Positive Organizational Scholarship (POS) provided one way to measure compassion. It proposes that compassion estimation should concentrate on the grouping of critical interpersonal communications between individual states or behaviors (Cassell, 2002; Neff et al., 2007). The present analysis operationalizes compassion in the light of this approach by raising four individual variables that are extensively involved in the compassionate practice, as considered by the previous model and investigation (Cassell, 2002; 
Neff et al., 2007). Such individual's elements are a) empathic or otherwise concerned with the emotional reaction induced by and consistent with the obvious well-being of a person that really needs it (Batson \& Ahmad 2009, p. 6), b) common humanity / identifying that pain, disappointment, and insufficiencies are essential for the human state instead of considering individuals as detached, quarantined, and not deserving of consideration (Neff 2003), c) Kindness/opening attention to the misery of others and does not disregard or disengaging from all of this, so that these feelings of kindness and ability to relieve their hardship arise (Neff, 2003; Wispe, 1991) and d) mindfulness/consciousness' state that reflects on current instant occurrences that arise both internally and externally (Dane 2011, p. 1000) or It is an open and conscious consideration of current occasions and practice. (Brown et al., 2007: 212). These four individual factors of workplace compassion form the basis of this research.

When OCBs follow peer-centered organizational strategies, this may be the last step in an ethical leadership practice of compassion that reacts out of the concern (Dutton et al., 2007; Frost, 1999; Lilius et al., 2011). However, the ethical leadership can contribute them to support additionally concerned emotions; followers who embrace ethical leadership may be conscious of their peer's problems and difficulties, and participate in interpersonal OCBs based on them (Batson, 1994; Davis, 1983) to assist their colleagues in troubles (Clark, 1997; Frost et al., 2000).

Another important factor the helps the ethical leader to deliver is through enhancing the perception of justice. As mentioned by, (Brown, Treviño, \& Harrison 2005), leaders of an organization have an enormous effect on their followers' work results, where leaders are trustworthy, practical, and principled, using a reward and punishment process and various components of correspondence to influence individuals' ethical actions. Earlier research has viewed the minimal convergence of this ethical leadership and corporate justice, despite the fact that there is an overwhelming consensus on the importance of ethical leaders.

Moreover, Tang, (2015) states that organizational justice is considered to be essential to the administration or organization as injustice has many "dark" outcomes and offers basic and viable presumptions to analysts in business ethics. Organizational justice perceptions can improve the employee's performance at the workplace. That includes expectations of incentives, outcomes, and engagement in decision-making. In this study, because of the related inquiries into organizational justice and the conditions of a community, organizational justice acts as a mediator in the connection between ethical leadership and Organizational Citizenship Behavior (OCB).

\subsection{Problem Statement}

Sometimes organizations do not do justice with their people, they fail to achieve their desired outcome, and this feeling of injustice creates stress among employees, and they start stealing in the name of the organization. Mostly organizations in Pakistan not recognizing the importance of Organizational Justice and workplace compassion, that's why they are failing in achieving their employees' extra-role behavior. Further, this research model is not extensively examined in Pakistan which might lead to employee's organizational citizenship behavior. A lot of investigations have been done to recognize the significance of workplace 
compassion and organizational justice in achieving the organizational objectives and goals through citizenship behavior or employees because this citizenship behavior of employees is not formally addressed in their job description and depends on their choice.

Recent examinations and outcomes have recognized compassion to be a fundamental aspect of a dynamic workplace. Indicating compassion to co-workers, managers, or subordinates, are crucial to maintaining work satisfaction and business-related motivation. Furthermore, Stringer (2002) stated, several examinations have publicized that the absolute most significant determining factor in the organization's environment is the consistent behavior of the organization's leader.

Organizations in today's competitive environment are constantly seeking new ways for maximizing the performance of their employees and there is a strong agreement on the idea that the performance of the organization is greatly influenced by the employee's extra-role behavior. But this behavior is determined as an outcome of the perception of justice. Jafari and Bidarian (2012) examined how to behave and treat employees will affect their future attitudes and behaviors. Moreover, Kuvaas and Buch, (2018) states that the business world is further turning into a keen observer of an abundance of unethical leadership activities taking place in the globalized business world other than its monetary concerns. Society's concern for organizational efficiency and Organizational Citizenship Behavior (OCB) has been created by the success of these problematic unethical management practices (Namoga, 2017).

Organizations retain their employees motivated to obtain target output. This motivation largely influences the employees' perceptions of the rewards obtained from the employer. Organizational justice is the best tool to encourage employers and employees to work together productively. In the absence of justice, employees may observe they are unjustly employed since their efforts are apprehended or rewarded. If their efforts are properly honored with reasonable rewards they will work hard. Further, leading with compassion allows us to understand the emotional reality of our colleagues thus providing a foundation for initiating positive change.

\subsection{Gap Analysis}

An investigation of the published research found that much of the research centered on results of the ethical leadership, where role models were moral administration and a two-way association between colleagues and leaders examined by some studies (Hansen, Alge, Brown, Jackson, \& Dunford, 2013; Avey, Wernsing, \& Palanski, 2012; Schaubroeck et al., 2012; Kacmar, Bachrach, Harris, \& Zivnuska, 2011; Mayer, Kuenzi, \& Greenbaum, 2010; Mayer, Kuenzi, Greenbaum, Bardes, \& Salvador, 2009; De Hoogh \& Den Hartog, 2008).

Few studies that concentrate on the elements or determinants of moral initiative in the earlier review (Brown \& Mitchell, 2010). Kalshoven, Den Hartog, and De Hoogh, (2011a); Walumbwa and Schaubroeck (2009), stated that with the followers' assessments of ethical leadership, two of the qualities that are leader thoughtfulness and conscientiousness are defined. Moreover, Jordan, Brown, Treviño, and Finkelstein (2013) analyzed in one research 
on the components that the ethical leadership is positively associated with the cognitive moral enhancement of the leader and considered to be strongest when his moral cognitive enhancement deviated from and higher than his employees' morale cognitive enhancement. Mayer, Aquino, Greenbaum, and Kuenzi (2012) mentioned that ethical leadership defined all the stages of the moral personality of the leader, specifically internalization and symbolization.

Some well-known researchers, (Yidong, \& Xinxin, 2013; Zheng et al., 2015; Hongwe, Linda, Melody, \& Weigle, 2015; Xu et al., 2016) posed concerns about the direct correlation of the ethical leadership with organizational citizenship behavior (OCB) in various research studies.

Even though OCBs have used behavioral practices in the organizational environment to forecast acts ethically (Colquitt et al., 2001; Trevin et al., 2006; Zoghbi-Manrique-de-Lara \& Sua'rez-Acosta, 2014). The present study overlooked the question of whether ethical motivation is the product of the previously endorsed positive responses to ethical leadership with the behavior of peer-focused citizenship (e.g., Avey et al., 2011; Kacmar et al., 2011; Mayer et al., 2009). As an effect of social exchange or social functioning behaviors, earlier research tends to emphasize these responses to ethical leadership, as well as results of behaviorist-formed social learning, if supporters believe that their leaders are reasonable and trustworthy. At the same time, because of ethical leadership, followers will also be expected to be ethically emotionally relevant and perform peer-focused OCBs based on ethical motivation.

Concerning this, several studies such as (Dickson et al., 2001; Haidt, 2006; Vianello et al., 2010; Diessner et al., 2013; Dutton \& Ragins, 2007) are carried out via workplace compassion and foster healthy interpersonal relationships linked to the ethical leadership with Organizational Citizenship Behavior (OCB).

However, the perspective of the Organizational Citizenship Behaviors (OCBs), in particular, Interpersonal Organizational Citizenship Behaviors (OCBI), is not much understood about how these moral structures such as compassion make it possible for the behaviors of leaders to produce follow-up consequences. We have proposed a theoretical framework, for this reason, thus adapting the model of Zoghbi-Manrique-de-Lara and Viera-Armas (2019) to integrate Organizational Justice.

Zhu, Treviño, and Zheng (2016); explored additional characteristics of a leader's moral identity in the previous study, with the ethical concern as an element of the perceived ethical leadership. Very few scholars predicted that perceived fairness is a significant component of ethical management. The organizational structures have been essentially affected by ethical leadership based on earlier examinations (Camps, Decoster, \& Stouten, 2012). The position of the organizational justice's dimensions (i.e. procedural justice, distributive justice, and interactional justice) may therefore be viewed as considerations for ethical leadership. Moreover, a link between the conduct of ethical leadership and corporate justice is established by analyzing ethical leaders as ethical agents of any organization. The moral conduct of leadership enhances the organization's positive behavior of subordinates such that their commitment to the organization is increased and Corporate Citizenship Behavior (OCB) 
further leads (Xu et al., 2016).

Hence, this investigation will expand and cover the ethical leadership and Organizational Citizenship Behavior (OCB) gap with regards to moral mechanisms that included compassion and organizational justice. In doing this, another concern will be examined in this research work, like, Are the organizational justice (i.e. distributive justice, procedural justice, interactional justice) and workplace compassion (i.e. empathic concern, common humanity, kindness, and mindfulness) act as a mediator in association concerning ethical leadership with Interpersonal Organizational Citizenship Behavior (OCBI)? Also, this research verifies the direct link between ethical leadership and Interpersonal Organizational Citizenship Behavior (OCBI).

This is a novel attempt as no such study used both moral factors i.e. Workplace Compassion, and organizational justice as mediators in a unified structural framework to explain how ethical leadership influences OCBI. Moreover, as such, no study has done in the Pakistani context.

\subsection{Research Objectives}

Focusing on the identified gaps, the present investigation aims to determine the influence of the ethical leadership on Interpersonal Citizenship Behavior (OCBI) through the mediating role of workplace compassion and organizational justice in several organizations employed in different sectors of Pakistan. Various determinants of workplace compassion (i.e. empathic concern, common humanity, mindfulness, and kindness), and organizational justice (i.e. procedural justice, distributive justice, and interactional justice) were used as mediating variables.

\subsection{Research Questions}

1) Does Ethical Leadership significantly related to the factors of workplace compassion (i.e. empathic concern, common humanity, kindness, and mindfulness)?

2) Does Ethical Leadership significantly related to the dimensions of organizational justice (i.e. procedural justice, distributive justice, and interactional justice)?

3) Does Interpersonal Citizenship Behavior (OCBI) significantly related to the factors of workplace compassion (i.e. empathic concern, common humanity, kindness, and mindfulness)?

4) Does Interpersonal Citizenship Behavior (OCBI) significantly related to the dimensions of organizational justice (i.e. procedural justice, distributive justice, and interactional justice)?

5) Does Workplace Compassion have a mediating effect on the relationship between ethical leadership and interpersonal citizenship behavior (OCBI)?

6) Does Organizational Justice have a mediating effect on the relationship between ethical leadership and interpersonal citizenship behavior (OCBI)? 


\subsection{Significance}

Leadership is an influence relationship that can have both a positive and negative impact on followers. In deciding the ethical climate of the organization, the present inquiry will help the managers or leaders. As we probably aware of the ethical climate in the organizations would improve employee's Organizational Citizenship Behavior (OCB) and trust in the organizations positively. Moreover, in Pakistan, the organization's circumstances will benefit from this investigation as the current research depends on the influence of the ethical leadership in the Interpersonal Organizational Citizenship Behavior (OCBI) while focusing on the mediating effect of compassion and justice in the workplace. Ethical managers can establish priorities in both execution and monetary problems by manipulating their organization's environment. Both supervisors and managers will benefit from this research to understand the significance of the organization's ethical and reliable environment.

Observing that if moral mechanisms motivate the influence of ethical leaders on peer-focused OCBs can focus on providing better ways for associations to enhance the quality of workplace relationships, and therefore, an enhanced role of the workplace.

This research study gives benefits to all those managements who want to achieve employee's desired behavior with the help of organizational justice and enhance the staff's motivation and excite them for activities beyond their designed responsibilities.

\section{Conceptual Framework}

\subsection{Ethical Leadership}

Brown et al. (2005) explain that in a two-way contact, acceptance, and followers' decision-making, ethical leadership refers to a presentation of individual acts and interpersonal relationships of morally acceptable conduct and promotion of such behaviors.

Ethical leaders (Treviño, Hartman, \& Brown, 2003) have been identified as both 'moral individuals' and 'moral managers.' The 'moral individual' view perceives the motives, besides the person characteristics of good pioneers, portrayed as conscious, genuine, trustworthy, honest, persuasive, and fair-minded (Brown, Treviño, \& Harrison, 2005). Moral minds are focused on making estimates subject to moral decision-making principles in both human and professional lives. The 'moral manager' view shows that these pioneers are setting and transmitting moral principles and goals, not only organizing their specific practices and various graduate schemes to meet moral standards, but also proactively using rewards and influence to hold followers responsible for moral directness (Brown \& Mitchell, 2010).

A case study was conducted by Treviño et al. (2003), in which senior managers and compliance officers investigated medium-to-large American organizations to determine ethical leadership beyond personal leadership. The findings have shown that ethical leadership is not just integrity and merit-based leadership motivation. It has an underestimated transactional aspect that requires the use of teamwork and rewarding expertise to guide ethical behavior.'

Dadhich and Bhal (2008); suggested that moral leadership conduct not only affected the 
moral conduct of workers but through the ability to predict work-related behavior, it also had practical significance. Neubert, Carlson, Kacmar, Roberts, and Chonko (2009) have found ethical leadership as a mediator had, directly and indirectly, influence on employee satisfaction and their emotional contribution to the ethical climate. The direct influence was attributed to role modeling and the indirect effect mostly on the organizational atmosphere. Although theoretical associations are in the early stages of research and assessment between perceived ethical leadership and employee behavior, these fundamental studies encourage and endorse the study's expansion (Brown \& Mitchell, 2010; Brown et al., 2005; Kouzes \& Posner, 2008; Mayer et al., 2009).

The theory of social learning applied to ethical leadership was explained by Brown and Treviño (2006a); Brown et al. (2005); Mayer et al. (2009); Thomas, Schermerhorn, and Dienhart (2004), as a way to explain the underlying process by which their adherents are motivated by moral leaders. The concept of the social learning theory holds that individuals can study each other through direct interaction as well as research (Robbins \& Judge, 2007). Leadership has accomplished by two facets of the social learning theory: a) attractive role modeling, and b) positive-strengthening of actions. Their integrity and altruistic intent are unusually appealing to ethical leaders. Owing to their involvement and position within organizations, they are also viewed as trustworthy. Their ability to influence performance and monitor benefits improves modeling process effectiveness. Social learning theory cooperates with the learners' job who have suggested over time that leadership theory is a central component of management and morals (Avolio, Walumbwa, \& Weber, 2009; Bass, 1999; Brown et al., 2005; Kouzes \& Posner, 2008). This theory also suggests awards and disciplines are deemed equivalent and reinforce ethical leadership standards (Mayer et al., 2009).

In social learning theory, Bandura (1977) clarified the protective impact of ethical leadership on deviant or unethical behavior. (Walumbwa et al., 2011; Walumbwa et al., 2012) discussed how Social Exchange theory has historically been used to describe why ethical leadership, such as job success and organizational citizenship behaviors (OCBs), has a positive effect on the actions of desired followers. Furthermore, the effectiveness of OCBs can be noted by followers as an efficient way to react to their representatives' ethical behavior.

The theory of social exchange by Blau (1964) was taken from most parts of this theory used to describe ethical leadership. This theory states that social exchange is a mutual practice of people who are inspired by the advantages that others are expected to offer and are typically brought about by them (Blau, 1964, p. 19). According to Brown and Treviño (2006), the theory is that when subordinates are treated fairly and ethically with respect, they would feel obligated to return the favor by displaying more acceptable actions, dedication, and efficiency. Brown and Treviño (2006) further claimed that ethical leadership is an organizational priority and has been shown to have a positive connection with employee behavior.

\subsection{Workplace Compassion}

Compassion was defined by Goetz et al. (2010) as an emotion that emerges in the observation of others' sufferings and encourages a corresponding need to help others. Kanov et al. (2004) stated three compassion sub-processes (i.e., remembering, experiencing, and responding), as 
described earlier. It is a significant first step to pay attention to or note the distress, which means being conscious of the other's need for support. The compassionate feeling is associated with empathic concern in the next step (Batson, 1994; Davis, 1983), a connection that indicates 'suffering' with others. Finally, a compassionate approach means taking steps to minimize or eliminate the need for the help of the other individual (Clark 1997; Frost et al., 2000). Moreover, Lilius et al. (2011) also clarified that Compassion is referred to as an interpersonal mechanism that requires three steps: recognizing, feeling, and reacting. It also includes several states, acts, behaviors, or feelings that can be clarified as to why compassion has been evaluated in different ways.

Earlier compassion literature shows a spectrum of optimistic behaviors that are interested in topics of compassion. These practices contain supporting others with tasks relating to work (Anderson \& Williams, 1996), giving empathy or assisting employees with particular issues (Kahn, 1998), peer support (Flynn \& Brockner, 2003), and peer collaboration (Dukerich et al., 2002). Organizational Citizenship Patterns further encourage the behavior. Organ (1988) presented OCB's influential explanation, arguing that it is a discretionary different activity that is not expressly identified through the legal incentive structure and that; overall, it preserves the organization's proper functioning. Moreover, the Theory of Contextual Performance, Organ (1997) by Borman and Motowidlo (1993) verified this explanation and later claimed that OCBs are an activity that promotes the social and psychological atmosphere in which tasks' performance takes place.

Compassion's ethical dynamics are associated with the compassion appraisal approaches of the Positive Organizational Scholarship (POS) and Positive Organizational Ethics (POEs) and dedicated with compassion, as a philosophy and study of primary field (Dutton \& Glynn, 2008; Dutton et al., 2007).

Social learning theory is one of the widely cited ways in which ethical leadership can make a significant contribution to conditions in the moral world and workplace compassion. The theory of social learning by (Bandura, 1977) proposes that they use this information to direct their actions as workers interpret the results of others' actions (such as leaders). This higher accountability of followers to fairer leaders' moral guidance illustrates the essential part of ethical leadership in the cultivation of principled conditions in the company's workgroups. Self-interest, companionship, and personal values are facets of the ethical climate at work at the individual level, widely recognized in previous research (Victor \& Cullen, 1987).

Positive Organizational Ethics (POE) suggests that egotistic self-interest's feelings, unlike companionship and individual morality, lead employees to be less capable to recognize their standards and interests (or self-consciousness), and to minimize the likelihood of recognizing the need for peer help, decreasing peer-to-peer capacity (Zoghbi-Manrique-de-Lara \& GuerraBaez, 2016; Hallowell, 1999; Frost de-Lara \& GuerraBaez, 2016) if peers or workers note any negative effects of egotistic self-interest's feelings in terms of sympathy in the workplace, ethical leader's behavior will give rise to sympathy among the followers. Studies showed that focusing on compassion at the workplace promotes healthy interpersonal relationships (Dutton \&Ragins, 2007). 


\subsubsection{Eliciting Moral Elevation}

Another way in which ethical leadership can contribute towards the prediction of compassion in the workplace is through assistance, emotional response to spiritual beauty standards, or moral quality (Haidt, 2006). As a result, Vianello et al. (2010) examined the argument that the ethical competence of leaders, (interpersonal justice and self-sacrifice), is a strong force for ethical growth, and the impact of leaders on OCB supporters is completely mediated by this emotion. Therefore, Ethical leaders may also play a fundamental role in developing moral values for their subordinates by evoking the emotion of moral change that can help followers to show interest in actions and involvement of their leaders (Dickson et al., 2001). The empathic concern is scientifically and logically connected with ethical advancement, according to Diessner et al. (2013); so that we have concluded, leaders who demonstrate empathic concern for their employees will also give rise their followers to be more moral and emotional empowerment and more empathic concern for them. Based on a principled motive or a moral obligation, workers would then be more likely to show empathic interest (Folger et al., 2005).

We therefore set down the following hypotheses:

H1a: Ethical leadership has positive effects on empathic concern.

\subsubsection{Humanity}

Although leadership is a phenomenon in the group, it is important to partly pass employee contact with an ethical leader to the workgroup of followers and coworkers (Ambrose et al., 2002; Rupp \& Cropanzano, 2002). A rationally self-interested and individualistic orientation, i.e. "What's for me in it?" (Trevin Apoyo et al., 2006), has been adopted by studies on the reactions to the suffering of others. Some prior studies, however, indicate that team workers can also respond by the moral obligation to the pain and suffering of colleagues (Folger, 2001). As such, employee respect for him/her will always benefit the section of the business he/she is responsible for in the benefit of the boss as a source of ethical advice (Ambrose et al., 2002; Rupp \& Cropanzano, 2002). The basis of concerning relationships is high-quality interactions categorized by positive respect of an individual's feelings for others which are important and have a sense of involvement (Dutton \& Ragins, 2007).

Assumptions regarding outcomes of work, however, may continue to realize peer interactions as exempted, or isolated; i.e. lack of common humanity, from larger human experience (Neff et al., 2007). For example, Messner and Rosenfeld (2001, p. 63) concluded that the exaggerated emphasis towards job results is 'conducive to the attitude' that how you play the game, either you win or lose. 'This absence of interest in something other than winning can contribute to an atmosphere of spiritual lack of comprehension that can contribute workers to believe that suffering is just a matter of themselves and alienation from themselves.'

Brown et al. (2005), defined an ethical leader as the one who describes success, not only in terms of efficiency but also in terms of how they are accomplished. As part of a broader human experience or circumstance, ethical leaders should also transform the inflated self-interest egotistical thoughts of their workers into peer judgments (Eisenberg, 2000; Parker \& Axtell, 
2001). As Karakas and Sarigollu (2013) have said, in the benevolent environment, people are most likely to provide measurable assistance, acts, or outcomes for the 'common good.' Finally, through reacting to ethical leadership, employees can be guided to a more integrated workplace where the traumatic experiences of peers are closer, that is, not isolated and detached from larger human experiences.

We therefore set down the following hypotheses:

H1b: Ethical leadership has positive effects on common humanity.

\subsubsection{Mindfulness}

Several "toxins" that cause discomfort and the need for occupational assistance have been cataloged by Frost (2003), and the attainment values can be an example (Messner and Rosenfeld 2001, p. 61). The values of achievement apply to the evaluation of particular value mostly based upon an initiative's results (Cullen et al., 2004). They foster specific concern with the acquisition of material and other strategic objectives where the means are in the context (e.g. peers) (Passas, 1995). Employees may also be unpleasant to colleagues since they are primarily interested in concentrating and ruminating on certain obsessions with the accomplishment of content and other strategic targets (Nolen-Hoeksema, 1991). This type of psychological inflexibility is referred to as 'over-identification' and promotes an exaggerated concentration, contrary to mindfulness, on the individual's stressful beliefs and emotions that isolate them from the situation (Atkins \& Parker, 2012). An ethical perspective that contributes to peer sympathy will be hard for workers to consider (Bennett-Goleman, 2001). An earlier study has shown that leadership integrity is strongly linked to mindfulness (Goldman-Schuyler, 2010; Waddock, 2001). When moral leaders usually function under forms of mindfulness, social learning (Bandura, 1977) is likely to build organizational mindfulness and relaxation habits that can also contribute to mindfulness for followers.

Therefore, we establish the following hypotheses:

H1c: Ethical leadership has positive effects on mindfulness.

\subsubsection{Kindness}

Egotistic feelings can make workers feel compelled to compete in pursuit of personal accomplishment against superiors, and They can be certain that universal values do not extend to them [the moral disengagement of Bandura $(1986,1999)$ ] or that They are "behind the limits of the application of moral principles, rules, and concepts of justice" [Opo-tow's, 1990:1) moral exclusion]. In favor of individual interests and feelings of distrust towards colleagues, these feelings may lead workers to neglect working relationships (Andersson \& Bateman, 1997). The egotistical concerns of employees should not make room for sympathy or positive peer reviews, as the needs of colleagues for support can be considered unnecessary or unrealistic and thus not deserving of consideration (Simpson et al., 2014; Dutton et al., 2010).

In terms of ethics, ethical leaders have been identified as being able to address corporate morals or standards with staff and set an example of the best way to do it. Such leaders believe that misery is reciprocal (Dutton et al., 2010) and that relationships of high standards are respected 
(Eisenberg, 2000; Parker \& Axtell, 2001) or that organizational and working group principles are respected (Ashforth et al., 2000; Clark, 2000). Hence, ethical leadership, based on social learning theory (Bandura, 1977), can turn egotistic feelings into benevolence. As a consequence, employees who consider ethical leadership as more likely to be morally motivated to respond to the essential for support from colleagues (Brown, 1999). These conditions are more likely to be deemed inevitable, understated, or well-deserved (Dutton et al., 2010), cause activate compassionate peer decisions and contribute to the greater likelihood of displaying compassion and making positive decisions about discomfort or mildness among peers.

Therefore, we establish the following hypotheses:

H1d: Ethical leadership has positive effects on kindness.

\subsection{Organizational Justice}

As Brown, Treviño and Harrison (2005) have noted that leaders of the organization have a major effect on the working actions of their followers where the leaders are trustworthy, truthful, principled, exercise a compensation and punishment process, and have distinctive mechanisms of communication to influence people's ethical behavior. There is, however, a general emphasis on the definition of ethical leaders, yet the reported study has found no convergence between this ethical leadership and corporate justice.

Northouse (2001) noted that "leader fairness" as a central element of ethical leadership identified this justice as a principal measure for ethical leaders as it leads to the equal and comparable practice of others. Distributive justice was perceived to be the fundamental predictor of two different outcomes, compensation, and work efficiency, followed by procedural justice. Also, procedural justice and distributive justice are fundamental to expect positive outcomes (Xu, et al., 2016).

Treviño and Brown (2004) established as one of the most important measures through which ethical leaders can convey anticipated actions could be the reward system. Organizations can foster both workplace value and ethical action by designing promotional and compensation models that reward ethical actions. Ethical leaders aim to improve the conduct of workers who strive for success without compromising principles.

Besides, in past research (Brown et al., 2005; Ponnu \& Tennakoon, 2009), the association between ethical leadership and leader's effective belief, the dedication of positive results of job devotion, leader happiness, and employee performance were examined. Ethical leaders, as shown in research by Mayer et al. (2009), are significant role models in shaping constructive behavior among workers. A negative association between ethical leadership and deviance was identified from society and a positive relationship at the workgroup level among ethical leadership and enhanced organizational citizenship behavior.

In essence, leaders will determine the conduct of organizational citizenship within their organizations. Role modeling (Treviño et al., 2000) is one of the major methods. Altruism and the present acts of citizenship itself excite ethical leaders. An effective leader should be 
attractive, honest, and trustworthy, based on the theory of social learning. These characteristics, which reflect the proper working environment and appropriate leadership behavior reflect the altruistic motivation of the leader. Daily interaction and promotion of organizational citizenship behavior among workers are followed by the following attraction (Brown et al., 2005).

Employee perspectives on workplace equity are known as Corporate Justice. This focuses on viewpoints on workplace reasonableness (Greenberg, 1990; Angelidis \& Nabil, 2011) and contains three components (Colquitt, 2001): (a) procedural justice, (b) distributional justice, and (c) interactional justice. The past efforts of management scholars have given great importance to organizational justice. According to Tang (2015), corporate justice is relevant to management literature, since inequality has many dark effects and offers fundamental and practical consequences for business ethics researchers Adam's work on equity theory has begun a review of fairness in physiology. It concentrated on distributive justice, i.e. the fairness of the results that one receives, in the name of the justice system in the workplace. By the time, the focus of the study turned to procedural justice (i.e. the supposed fairness means used to accomplish an objective). Niehoff and Moorman (1993) broadened the idea of interactive justice, which is referred to as the social communication between workers and their employers. Based on this, these three aspects of corporate justice are explored by the organization's researchers.

There was some controversy regarding the philosophical position of interactive justice. Bobocel and Holmvall (1999a; 1999b) appeared to see it as a procedural justice factor, whereas it was seen as distinct by others. For some exceptions, Clayton and Opotow (2003), many modern academics seek to analyze interactive justice separately from procedural justice (Ambrose \& Arnaud, 2005). That is actually due to additional methodological enhancements by Bies (2001). Bies (2001) indicates there are at least four facets of contact inequality i.e. mean-spirited assessment decisions, dishonesty, privacy breaches, and absence of consideration (Roch \& Shanock, 2006). As a result, several scholars consider the three-factor model of justice perceptions (distributive justice, procedural justice, and interactional justice).

Colquitt (2001) further subdivided conceptions on justice, arguing that different constructions should be seen, as the two dimensions described by Bies and Moag (1986) and Bies (1987). He described the former as "interpersonal-justice", and later as "knowledge-justice." He offered experimental support and context-analytical analysis consistent with his stance (Masterson, Byrne, \& Mao, 2005) (Colquitt, Conlon, Wesson, Porter, \& Ng, 2001). Colquitt's work lays down the four-factor organizational justice model, i.e. distributive, operational, interpersonal, and informational. Note that it is not incompatible with the three-and four-factor versions. They can be viewed specifically, as distinct variables more generally, such as the single dimension of interactional justice since knowledge and interpersonal justice are intertwined (Ambrose \& Arnaud, 2005; Ambrose, Hess, \& Ganesan, 2007).

Ethical leadership and organizational citizenship activities of workers are interrelated based on two psychological processes (i.e. social learning and social exchange), according to a previous empirical study by Mo and Shi (2017). The Social Learning Mechanism is where 
workers mimic their leaders 'actions, and one that connects ethical leadership to corporate justice and also to workers' corporate conduct is the Social Exchange Mechanism. Furthermore, the research revealed a correlation between ethical leadership and employees' manners in terms of corporate citizenship mediated by procedural justice.

A variety of evidence has been established by prior empirical research in favor of the affiliation amid ethical leadership with corporate justice. Xu et al. (2016) investigated, Workforces are more likely to trust and support their work under equitable conditions and ethical leadership and are more confident that the advantages of organizations are shared equally (Colquitt et al., 2001). Employees are also more likely to perceive the choices and job well-being of their supervisor more favorably when handled fairly by their ethical leader.

\subsubsection{Distributive Justice}

Distributive justice impacts workers in views of management and living conditions and profits. Furthermore, Oshio and Kobayashi (2009); Schyns, (2001) found that, when higher distributive justice is perceived, their enhanced psychological status and overall conduct leads to greater distributive justice. Camps et al. (2012), on the other hand, analyzed self-serving leaders as leaders who put the interests of their followers and the organization's goals above their interests and well-being. Findings have shown that distributive justice works as a method of shielding workers from potentially detrimental self-serving representatives. It should also be remembered that leaders who give priority to their well-being might still partly act ethically (Gino, Moore, \& Bazerman, 2009). Their research also showed that when judging the ethical behavior of others, workers tend to accept the fairness of outcomes.

Moreover, subordinates deal with a leader who put first his/ her self-interest but maintains fairness in appearance, is superior at dealing with the personal consequences of that leader's behaviors. More studies have just been able to demonstrate that, under specific conditions, an employee's organizational identity has a positive relationship with non-ethical pro-organizational behaviors. Umphress, Bingham, and Mitchell (2010) have shown that in circumstances, where workers have to contend with wit, Thau, and Mitchell (2010), have presented evidence of the adverse effects of distributive justice.

De Cremer (2007) has studied that when workers oppose certain types of leaders (i.e. a leader who has been forced into making decision practice), distributive justice has no positive/ negative impact on employees' feelings. Based on these claims, this proposed paradigm also implies that distributive justice increases workers' understanding of ethical leadership in the workplace. Besides, employees' perceived distributive justice is directly linked to the perception of employees.

\section{H2a: Ethical leadership has positive effects on Distributive Justice.}

\subsubsection{Procedural Justice}

Procedural justices are created when staff inputs taking into consideration throughout making- decision practices, when consistency, accuracy, bias reduction, representativeness, proper-ability, and ethics practiced in procedures. Loi et al. (2012) studied the fact that 
commitment to organizational processes and strategies attracts employees' behavior and loyalty to the company's fair procedures. One research study found that greater procedural justice is shown by staff working with ethical leaders ( $\mathrm{Li}, \mathrm{Wu}$, Johnson \& Wu, 2012).

(Bal, de Lange, Ybema, Jansen, \& van der Velde, 2011) have discovered, the faith and confidence in the operation of the company have a central role to play in determining procedural justice at the workplace. Loi et al. (2012); De Cremer (2006) argued that fairness is impaired as workers gain trust in the organization. Recent observed studies have shown that in what way the link between ethical climate and attitudes to corporate justice affects the continuity of associations between managers and workers, and research has also shown there is a clear adverse affiliation among procedural justice and ethical climate (Burton, Peachey, \& Wells, 2016; Fein, Tziner, Lusky, \& Palachy, 2013). Hence, the existing research assumes procedural justice as a mediator in the organization's connection of ethical leadership with public conduct.

\section{H2b: Ethical leadership has positive effects on Procedural Justice.}

\subsubsection{Interactional Justice}

Earlier investigation and model found that compared to other types of fairness, Interactional justice between managers and employees has a more interactive effect. Further research has shown that, through interactional justice, leadership styles like (paternalistic leadership and transformational leadership), indirectly affect employees' loyalty to the organization, work-life efficiency, and confidence in superiors (Gillet, Fouquereau, Bonnaud-Antignac, Mokounkolo, \& Colombat, 2013; Wu, Neubert, \& Yi, 2007). The previous study agreed that the connection of interactional justice with ethical leadership based upon the features and values of the leader seen through his employees as normatively acceptable; these values contain honesty, compassion, trustworthiness, and fairness (Kalshoven, Den Hartog, \& De Hoogh, 2011b).

During their interpersonal interactions, leaders who demonstrate these behaviors can excite the subordinates' thoughts of being employed with dignity, honesty, and fairness. As a result, these thoughts served as hallmarks of interactional justice, which is mainly interpreted throughout interpersonal encounters between leaders and their subordinates with the fairness faced by staff. Also, Li et al. (2012) explored the affiliation between ethical management and emotional empowerment, i.e. value, effect, capability, and self-motivation. They also researched the part of interactive justice in this association. Findings have shown, interactional justice is associated with ethical leadership and subordinate's experience.

According to the prior study (Wang et al., 2015; Fein et al., 2013), the positive influence of subordinates' obedience to superiors and perceived Interactional Justice (IJ) has clarified. Their investigation proposed to examine the comparative strength of the correlations between the principled environment and the three forms of the conceptions of fairness. They noted a significant positive correlation between the level of managers and perceived interactional justice. Also, their investigation found that there were no significant correlations between other forms of views of justice and leaders. However, various findings obtain by some 
researchers.

Walumbwa, Hartnell, and Misati (2017); acknowledged fair treatment of the boss considered to be less critical to the supervisors than to the fair- treatment they receive from their employees. To achieve an objective, groups prefer to interact with and rely more on each other than on their representatives. Second, after determining the supervisor's ethical leadership conduct, the fair treatment given by the supervisor can be presumed to be a reduced unique variance in the peer justice culture. Fox, Spector, and Miles (2001) have indicated that in an ethical setting, negative feelings and perceptions arise from an unjust view of treatment.

H2c: Ethical leadership has positive effects on Interactional Justice.

\subsection{Interpersonal Organizational Citizenship Behavior (OCBI)}

In the Organizational behavior area, a central component of organizational performance is Interpersonal Citizenship Behavior (OCBI). It happens in the workplace when an employee goes beyond his or her structured job requirements to assist co-workers by engaging in activities such as assisting others who fall behind in their job and exchanging work-related data (Bowler \& Brass, 2006; Williams \& Anderson, 1991).

In 1987, Organizational citizenship behavior was first stated as extra-role behaviors by Kan and Katz. According to Bateman and Organ (1983), Extra-role performance behaviors are particular behaviors of employees, which are not part of their work requirements as they cannot be prioritized or required but do contribute to the efficiency of the organization as a social system.

The seminal principle of OCB was introduced by Organ (1988), explaining that "individual conduct is contextual, not acknowledged expressly or indirectly by the rewards scheme created, and therefore promotes organization's efficient functioning" (p. 4). In line with the definition of contextual conduct by Borman and Motowidlo (1993), Subsequently, Organ (1997) revised its description to explain; OCBs are' performance which supports social and psychological atmosphere in which task performance takes place (p. 95). Multidimensional principles e.g. conscientiousness, sportsmanship, social virtue, courtesy, and altruism have been distinguished from OCBs (Podsakoff et al., 1990).

Moreover, OCBs have further identified behaviors that are more important for supporting Organization Citizenship Behaviors as a whole (OCBOs), and behaviors that are specifically targeted at people inside the organization (OCBIs) (Williams and Anderson 1991). On the one side, conscientiousness (often referred to as compliance), sportsmanship (tolerance without complaint), and civic virtue are considered organizationally targeted (OCBOs) in this regard. Courtesy and altruism, on the other hand, are seen as facets of OCBs that benefit co-workers (OCBIs) mainly (Williams and Anderson 1991; Van Dyne et al. 1995). Courtesy described as the conduct of helping other members of the society by taking measures to avoid problems, and altruism describes as assisting others in their works (Organ, 1988).

Such Organizational Citizenship Behaviors (OCBs) are discretionary individual behaviors 
that managers extremely admire because they can boost the company's performance (Organ, 1988). There are supporting activities that may either organizationally-targeted forms, such as the institution's protection when others criticize, or independently-targeted forms, like arrangements that ensure employee human-being. Prior research advises that to inspire them, leaders use inherently inspired approaches (Kuvaas \& Dysvik, 2009; Piccolo \& Colquitt, 2006). This Interpersonal Citizenship Behaviors (OCBI) improve individual and community effectiveness, free up resources, increase communication and help sustain a favorable working environment even more than non-interpersonally based OCB (Podsakoff et al., 2000).

H3; Empathic concern (H1a), Common humanity (H1b), Mindfulness (H1c), and Kindness (H1d) have a significant positive relation with Interpersonal citizenship behavior (OCBI).

$\mathrm{H} 4$; Procedural justice (H2a), Distributive justice $(\mathrm{H} 2 \mathrm{~b})$, and Interactional justice $(\mathrm{H} 2 \mathrm{c})$ have a significant positive relation with Interpersonal citizenship behavior (OCBI).

\subsection{Mediatory Role of Moral Mechanisms}

Worker's expectations of equal treatment by the organizations have widely studied as a significant aspect of understanding why did staff want to engage in moral actions? (e.g., Cohen-Charash \& Spector, 2001; Greenberg, 1990, 2002; Weaver \& Trevin Apo, 1999; Masterson et al., 2000; Moorman, 1991). Researchers studied justice responses, like Moorman and Byrne (2005) and Conlon et al. (2005), who proposed several hypotheses as explanations for responses to workplace fairness, for instance, motivation based upon loyalty, trust, and faith in supervisors. Conversely, managers violating unjust and unethical actions of workers are possible to view as a lack of humanity that can adversely affect employee's beneficial responses to colleagues (Zoghbi-Manrique-de-Lara \& Sua'rez-Acosta, 2014). The unique tactic facilitating third party involvement proposed that employees should act as non-involved private individuals that are equally concerned with the need for assistance from their colleagues. The basis of this argument can found in specific employee-based leadership concepts (Bass, 1990; Lord et al., 2001), which show that previous ideas about the boss produce "schemes" can determine how workers view their manager's performance (and respond to it).

Workers are mostly linked to the moral relationship with the success of their successful managers which these "schemes" represent at the workplace. Similarly, this shift will describe whether they respond to their supervisors' success through generating ethical responses of OCBs in the context of peer-focused citizenship behavior (Bass, 1990; Lord et al., 2001). Certainly, past evidence supports this suggestion.

Firstly, leadership continuity appears to be based, on two distinct types of schemes, as "moral managers" and "moral citizens" are referred to as ethical leaders (Trevin Apocalypse et al., 2000). From ethical leaders, they are especially conscious of peer-to-peer consideration when implicit leadership concepts are moral comparisons of the success of real leaders as 'moral managers' at the workplace, so they will aim as moral administrators to ensure their team succeeds and provides compassionate support. In essence, the management style has shown to 
affect compliance in working group ethical decision-making processes (Schminke et al., 2002), and similarly 'ethical manager' attitudes represent the type of 'service system' in which there are supportive reactions towards ethical leadership in the context of peer-focused OCBs. Brief et al. (2001) underlined the importance of suggesting the way of thinking and acting that might constitute a sort of organizational moral environment, the isolated style of ethical thoughts and behavior that may partially be expressed by the moral manager. If the ethical leadership contributes kindness at the workplace, then this 'helping environment' is likely aligned with employee moral principles as implied via implicit leadership concepts, enhancing them, and as a result, fostering ethical actions as peer-focused OCBs.

Secondly, in the point of view of an ethical person, leaders, who ethically manage subordinates, is likely to be associated with workers consider as a respectable individual to be and to be embraced and liked. The caring feelings generated by ethical leadership among followers will increase this likely affinity for supervisors, finally, describing why workers respond to peer-focused OCBs to ethical leaders. In this regard, POEs suggests, they are typically more likely to build moral sensitivity when employees have positive attitudes (Handelsman et al., 2002), and compassionate responses.

\subsubsection{Compassion}

Weiss and Cropanzano (1996, p. 37) have taken implicit leadership theories into account and support the mediating role of compassion when they state that affective systems "appear to act as latent predispositions" and that people engaged in negative affectivity are "predisposed to react more strongly to negative events." Therefore, if ethical leadership is ultimately expected, as a result of an approach based on impacts (Folger et al., 2005), peer-focused OCBs responses of the employees to ethical leadership will include sympathetic feelings.

Therefore,

H5: Empathic concern (H5a), common humanity (H5b), mindfulness (H5c), and kindness (H5d) are positively mediate in the association between ethical leadership and Interpersonal citizenship behavior (OCBI).

\subsubsection{Organizational Justice}

According to Colquitt (2001), a general view about decisions on four forms of organizational justice, given procedural justice and their outcomes can be judged, like tasks, and if the inputs along with the proper protocol, being followed and then compared with other employees or organizations, were reasonably appropriate for the results. Next, distributive justice, which talks about views and their outcomes, is measured by the number of individuals getting; decision-making, hiring employees. Further, the next category is interpersonal justice, that measures the behavior of employees in an organization with respect and fairness. Informational Justice requires the understanding of the decisions/changes that arise in or relevant to the organization, whether the employee has adequate knowledge of existing decisions in the organization. Both interpersonal and informational justices are referred to as collaborative justice. The present study aims to connect these two justices and to present their findings. They are concerned with job results, company agreements, management appraisal, 
elimination, and performance (Cohen, Charash, \& Spector, 2001; Colquitt \& Conlon et al., 2001).

Interactional justice, as mentioned earlier, refers to the virtue and relational care of the pioneer. Interactional justice, contrasted with procedural justice; requires fewer formalized sections of dialogue (De, Coninck, 2010). Interactional justice combines the degree of trustworthiness, affectability, and reverence displayed by the contact pioneers (Colquitt, Conlon, Wesson, Porter, \& Ng, 2001).

Mostly observation on fairness having significant results related to work has a connection with workers' expectations on fairness in the contexts of the organization (Cohen-Charash \& Spector, 2001; Colquitt, Conlon, Wesson, Porter, \& Ng, 2001). These ideals of perceived fairness contain satisfaction with one's job and supervisor (Alexander \& Ruderman, 1987), employee act (Cropanzano, Weiss, Suckow, \& Grandey, 2000), organizational engagement (Masterson, Lewis, Goldman, \& Taylor, 2000), citizenship and counter-productive actions (Skarlicki \& Folger, 1997; Greenberg, 1990), and work success (Ball, Trevino, \& Sims, 1994). Prior research suggests, organizational justice is the appropriate process whereby ethical leadership is positively related to organizational citizenship (Yidong \& Xinxin, 2013; Hongwei, Linda, Melody, \& Weigle, 2015; Xu et. al., 2016; Zheng et al., 2015).

Therefore,

H6: Procedural justice (H6a), distributive justice (H6b), and interactional justice (H6c) are positively mediated in the association between ethical leadership and Interpersonal citizenship behavior (OCBI).

\subsection{The Study Model}

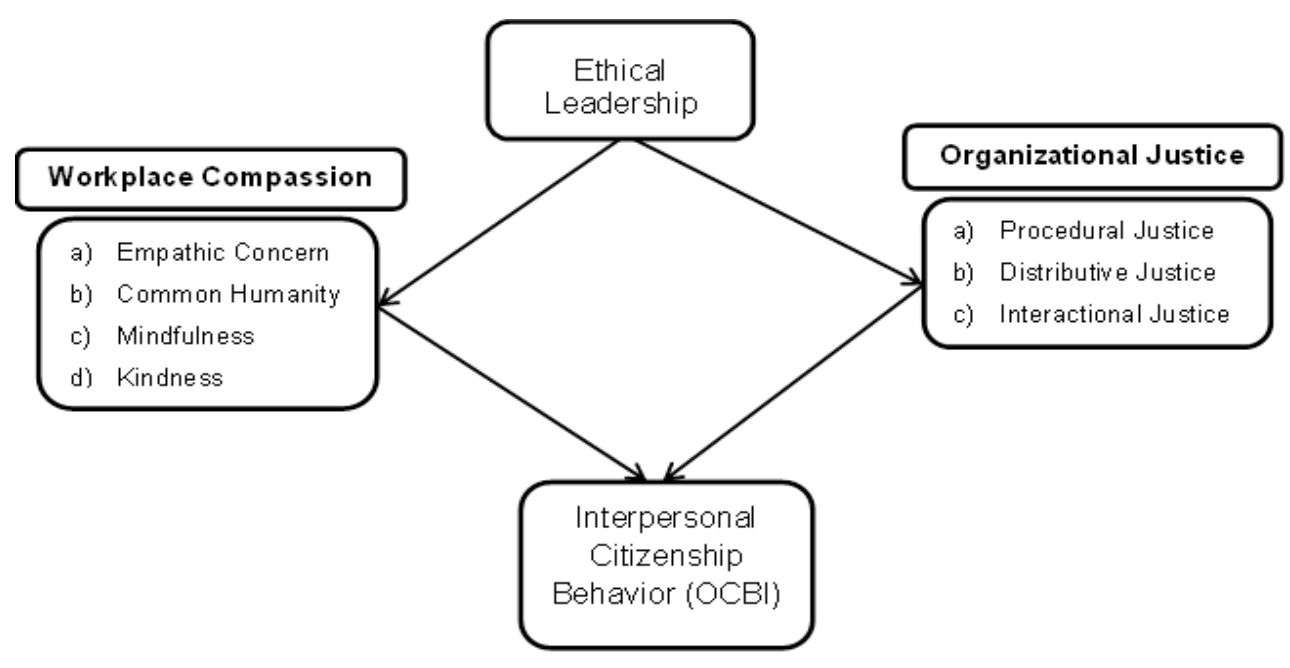

This study model explains the entire topic of research and the relationship of an independent variable (Ethical Leadership) and dependent variable (Interpersonal Citizenship Behavior (OCBI)). The four sub-constructs of Workplace Compassion (empathic concern, common humanity, mindfulness, and kindness) and three sub-dimensions of Organizational Justice (procedural justice, distributive justice, and interactional justice) are used in the present study to measure the ethical leadership relationship with interpersonal citizenship behavior (OCBI) 
whereas; these variables can study with other variables too. This relationship of Ethical Leadership and OCBI studied with the mediating effect of Workplace Compassion and Organizational Justice.

\section{Research Methodology}

\subsection{Sample and Procedure:}

In this study, we collected facts from 350 employees that comprise both male and female associated with different organizations in Pakistan. Responses mostly gathered from Finance managers or employees and employees related to Human Resource Management. After the collection of data, SmartPLS3 software was used to analyze the responses. The Partial Least Square (PLS) and Structural Equation Modeling (SEM) are descriptive statistics used to evaluate all responses to the standardized questionnaire and the statistical techniques used to interpret the results.

\subsection{Research Questionnaire Design}

The questionnaire comprises five sections: Demographic Characteristics, Ethical Leadership, Workplace Compassion, Organizational Justice, and Interpersonal Citizenship behavior (OCBI). The first section contains a demographical question that includes the gender and age of the respondent, and the other sections contain questions regarding the research variables.

\subsubsection{Ethical Leadership}

The six components of an ethical leadership test established by Brown et al. (2005) used to assess the ethical leadership: treating employees equally, listening, anxiety, faith, demonstrating behavior, and communication response. It includes 10-items and on the five-point Likert-type scale from 1 (Strongly Disagree) to 5 (Strongly Agree), responses estimated.

\subsubsection{Workplace Compassion}

D Empathic Concern: Empathic concern analyzed by Davis' (1980) Interpersonal Reactivity Index's 7-item Empathic Concern subscale measures feelings of warmth, care, and empathy for others.

Mindfulness: Mindfulness, evaluated using the Mindful Attention Awareness Scale (MAAS), which is an efficient indicator of mindlessness with an extended scientific track record. The short-scale MAAS, 6-item, (e.g., "It seems that I'm running on automatic pilot, without much awareness of what I'm doing,") established by Black et al. (2012), was preferred to ease the respondent burden. MAAS tests mindlessness, and subsequently reverse-coded the item ratings, with the higher scores specifying the higher-scale of mindfulness.

$>$ Kindness and Common Humanity: We incorporated the Self-Compassion Scale (SCS), subscales by Neff (2003) of 5-item Self-Kindness, and 4-item Common Humanity to assess Kindness and Common Humanity. Also, we changed their items and refocused on supportive behavior and emotions towards co-workers with self-compassion. Such as the item, 'I am 
kind to myself when I am suffering,' was replaced with, 'I am kind to peers when they suffer,' while the item, 'I try to see my shortcomings as part of the human condition, linked to the common humanity,' was replaced by, 'I try to see peers failings as part of the human condition.'

\subsubsection{Organizational Justice}

Organizational Justice, evaluated by using 20-items based on Colquitt's (2001) scale for employee's perception in the workplace. These 20-items, stated as Procedural Justice, Distributive Justice, and Interactional Justice.

$>$ Procedural Justice: The 7-item scale modified for the component, i.e. procedural justice that evaluated the fairness of procedures/practices in the workplace; and the degree to which procedures were enforced fairly, and uniformly to all. A sample of the things is, "Have you been able to express your views and feelings during those procedures?"

$>$ Distributive Justice: A 4-item was used to assess Distributive justice, which centered on fair pay, advancement, appropriate recognition, and incentives. A sample of the items, i.e. 'Does your outcome reflect the effort you put into your work?'

$>$ Interactional Justice: A 9-item was used to assess Interactional Justice, which refers to employee feelings on how managers handle their workers equally. A sample of the item is, 'Has your Superior politely treated you?'

\subsubsection{Interpersonal Citizenship behavior (OCBI)}

Interpersonal Citizenship Behavior (OCBI) was analyzed using Lee and Allen's (2002) 7-items of the OCBI scale. By focusing on peers, all things have rephrased.

\section{Analysis and Results}

\subsection{Demographic Analysis:}

Table 1. Frequency Distribution

\begin{tabular}{|l|l|l|}
\hline Variables & Options & Percentages \\
\hline Gender & Male & $75.2 \%$ \\
\hline & Female & $24.8 \%$ \\
\hline Age & Below 25 & $18.5 \%$ \\
\hline & $25-34$ & $59.3 \%$ \\
\hline & $35-44$ & $17.4 \%$ \\
\hline & $45-54$ & $4.6 \%$ \\
\hline & 55 and above & $0.3 \%$ \\
\hline
\end{tabular}

Source: Own research work processed in PLS-SEM.

The above table no. 1 of Frequency Distribution shows that $75.2 \%$ (264) males and $24.8 \%$ (86) females have participated in our research. The above table also indicates that $18.5 \%$ of respondents are under the age limit of below 25 years, $59.3 \%$ of the respondents under the 
age limit of $25-34$ years, $17.4 \%$ of respondents' age limit is $35-44$ years, $4.6 \%$ respondents are between the age limit of $45-54$ and only $0.3 \%$ respondents under the age limit of 55 and above.

\subsection{Descriptive Statistics}

Table 2. Descriptive statistics

\begin{tabular}{|c|c|c|c|c|c|c|c|}
\hline \multirow{2}{*}{$\begin{array}{l}\text { Variables and } \\
\text { Factors }\end{array}$} & \multirow{2}{*}{\multicolumn{2}{|c|}{ Questions }} & \multicolumn{2}{|c|}{$\begin{array}{l}\text { Descriptive } \\
\text { Stats } \\
\end{array}$} & \multicolumn{3}{|c|}{$\begin{array}{l}\text { Confirmatory } \\
\text { Analysis }\end{array}$} \\
\hline & & & Mean & S.D & $\begin{array}{l}\text { Outer } \\
\text { Loading }\end{array}$ & $\begin{array}{l}\text { T } \\
\text { Stats }\end{array}$ & P Values \\
\hline \multirow{10}{*}{$\begin{array}{l}\text { Ethical } \\
\text { Leadership }\end{array}$} & 1 & Makes fair and balanced decisions. & 0.679 & 0.066 & 0.681 & 10.335 & 0.000 \\
\hline & 2 & $\begin{array}{l}\text { Has the best interest of employees in } \\
\text { mind. }\end{array}$ & 0.670 & 0.055 & 0.673 & 12.183 & 0.000 \\
\hline & 3 & $\begin{array}{l}\text { Listens to what department } \\
\text { employees have to say. }\end{array}$ & 0.737 & 0.048 & 0.740 & 15.363 & 0.000 \\
\hline & 4 & $\begin{array}{l}\text { Disciplines employees who violate } \\
\text { ethical standards. }\end{array}$ & 0.491 & 0.080 & 0.493 & 6.156 & 0.000 \\
\hline & 5 & Can be trusted. & 0.684 & 0.042 & 0.688 & 16.223 & 0.000 \\
\hline & 6 & $\begin{array}{l}\text { Conducts his/her personal life in an } \\
\text { ethical manner. }\end{array}$ & 0.598 & 0.065 & 0.609 & 9.402 & 0.000 \\
\hline & 7 & $\begin{array}{l}\text { Defines success not just by results } \\
\text { but also the way they are obtained. }\end{array}$ & 0.700 & 0.060 & 0.707 & 11.745 & 0.000 \\
\hline & 8 & $\begin{array}{l}\text { Asks "what is the right thing to do?" } \\
\text { when making decisions. }\end{array}$ & 0.748 & 0.035 & 0.752 & 21.262 & 0.000 \\
\hline & 9 & $\begin{array}{l}\text { Discusses business ethics or values } \\
\text { with employees. }\end{array}$ & 0.724 & 0.041 & 0.731 & 17.657 & 0.000 \\
\hline & 10 & $\begin{array}{l}\text { Sets an example of how to do things } \\
\text { the right way in terms of ethics. }\end{array}$ & 0.813 & 0.030 & 0.817 & 27.487 & 0.000 \\
\hline \multirow{6}{*}{$\begin{array}{l}\text { Interpersonal } \\
\text { Citizenship } \\
\text { Behavior } \\
\text { (OCBI) }\end{array}$} & 1 & $\begin{array}{l}\text { Give up time to help co-workers who } \\
\text { have work or non-work problems. }\end{array}$ & 0.778 & 0.043 & 0.781 & 18.231 & 0.000 \\
\hline & 2 & $\begin{array}{l}\text { Adjust your schedule to } \\
\text { accommodate other colleagues' } \\
\text { requests for time off. }\end{array}$ & 0.708 & 0.045 & 0.713 & 15.705 & 0.000 \\
\hline & 3 & Assist peers with their duties. & 0.805 & 0.025 & 0.806 & 32.000 & 0.000 \\
\hline & 4 & $\begin{array}{l}\text { Go out of the way to make newer } \\
\text { colleagues feel welcome in the work } \\
\text { group. }\end{array}$ & 0.675 & 0.040 & 0.677 & 16.737 & 0.000 \\
\hline & 5 & $\begin{array}{l}\text { Share personal property with peers to } \\
\text { help their work. }\end{array}$ & 0.601 & 0.049 & 0.600 & 12.137 & 0.000 \\
\hline & 6 & $\begin{array}{l}\text { Willingly give your time to help } \\
\text { peers who have work-related }\end{array}$ & 0.777 & 0.031 & 0.779 & 25.284 & 0.000 \\
\hline
\end{tabular}




\begin{tabular}{|c|c|c|c|c|c|c|c|}
\hline & & problems. & & & & & \\
\hline & 7 & Help peers who have been absent. & 0.697 & 0.041 & 0.699 & 17.155 & 0.000 \\
\hline \multirow{4}{*}{$\begin{array}{l}\text { Workplace } \\
\text { Compassion } \\
\text { a)Empathic } \\
\text { Concern }\end{array}$} & 1 & $\begin{array}{l}\text { I am often quite touched by things } \\
\text { that I see happen to my peers. }\end{array}$ & 0.805 & 0.031 & 0.804 & 26.355 & 0.000 \\
\hline & 2 & $\begin{array}{l}\text { I often have tender, concerned } \\
\text { feelings for co-workers less fortunate } \\
\text { than me. }\end{array}$ & 0.733 & 0.046 & 0.738 & 16.024 & 0.000 \\
\hline & 3 & $\begin{array}{l}\text { I would describe myself as a pretty } \\
\text { soft-hearted person. }\end{array}$ & 0.612 & 0.059 & 0.618 & 10.513 & 0.000 \\
\hline & 4 & $\begin{array}{l}\text { When I see peers being taken } \\
\text { advantage of, I feel kind of protective } \\
\text { toward them. }\end{array}$ & 0.554 & 0.065 & 0.559 & 8.628 & 0.000 \\
\hline \multirow{4}{*}{$\begin{array}{l}\text { b)Common } \\
\text { Humanity }\end{array}$} & 1 & $\begin{array}{l}\text { When I see my co-workers down and } \\
\text { out, I remind myself that anyone in } \\
\text { the world can feel that way. }\end{array}$ & 0.794 & 0.042 & 0.792 & 18.915 & 0.000 \\
\hline & 2 & $\begin{array}{l}\text { When things are going badly for my } \\
\text { peers, I see their difficulties as part of } \\
\text { anyone's life. }\end{array}$ & 0.786 & 0.038 & 0.791 & 21.015 & 0.000 \\
\hline & 3 & $\begin{array}{l}\text { I try to see peers' failings as part of } \\
\text { the human condition. }\end{array}$ & 0.673 & 0.077 & 0.680 & 8.825 & 0.000 \\
\hline & 4 & $\begin{array}{l}\text { When I see my peers' inadequacies, I } \\
\text { try to remind myself that they are } \\
\text { shared by most people. }\end{array}$ & 0.778 & 0.040 & 0.785 & 19.437 & 0.000 \\
\hline \multirow{3}{*}{ c)Mindfulness } & 1 & $\begin{array}{l}\text { I rush through activities without } \\
\text { being really attentive to them. }\end{array}$ & 0.831 & 0.091 & 0.844 & 9.309 & 0.000 \\
\hline & 2 & $\begin{array}{l}\text { I find myself doing things without } \\
\text { paying attention. }\end{array}$ & 0.878 & 0.068 & 0.891 & 13.015 & 0.000 \\
\hline & 3 & $\begin{array}{l}\text { It seems that I am "running on } \\
\text { automatic pilot," without much } \\
\text { awareness of what I'm doing. }\end{array}$ & 0.835 & 0.080 & 0.846 & 10.571 & 0.000 \\
\hline \multirow{4}{*}{ d) Kindness } & 1 & $\begin{array}{l}\text { I'm tolerant of the flaws and } \\
\text { inadequacies of my peers. }\end{array}$ & 0.739 & 0.032 & 0.741 & 22.959 & 0.000 \\
\hline & 2 & $\begin{array}{l}\text { I try to be loving toward peers who } \\
\text { are feeling emotional pain. }\end{array}$ & 0.830 & 0.024 & 0.831 & 34.515 & 0.000 \\
\hline & 3 & $\begin{array}{l}\text { I'm kind to peers when they are } \\
\text { suffering. I'm kind to peers when } \\
\text { they are suffering. }\end{array}$ & 0.828 & 0.027 & 0.830 & 30.389 & 0.000 \\
\hline & 4 & $\begin{array}{l}\text { When some peer is going through a } \\
\text { very hard time, I give the caring and } \\
\text { tenderness s/he needs. }\end{array}$ & 0.807 & 0.030 & 0.809 & 27.289 & 0.000 \\
\hline Organizational & 1 & $\begin{array}{l}\text { Have you been able to express your } \\
\text { views and feelings during those } \\
\text { procedures? }\end{array}$ & 0.664 & 0.052 & 0.668 & 12.824 & 0.000 \\
\hline
\end{tabular}




\begin{tabular}{|c|c|c|c|c|c|c|c|}
\hline \multirow{6}{*}{$\begin{array}{l}\text { a)Procedural } \\
\text { Justice }\end{array}$} & 2 & $\begin{array}{l}\text { Have you had influence over the } \\
\text { (outcome) arrived at by those } \\
\text { procedures? }\end{array}$ & 0.702 & 0.057 & 0.708 & 12.511 & 0.000 \\
\hline & 3 & $\begin{array}{l}\text { Have those procedures been applied } \\
\text { consistently? }\end{array}$ & 0.663 & 0.063 & 0.672 & 10.599 & 0.000 \\
\hline & 4 & $\begin{array}{l}\text { Have those procedures been free of } \\
\text { bias? }\end{array}$ & 0.712 & 0.041 & 0.713 & 17.303 & 0.000 \\
\hline & 5 & $\begin{array}{l}\text { Have those procedures been based on } \\
\text { accurate information? }\end{array}$ & 0.758 & 0.036 & 0.757 & 21.183 & 0.000 \\
\hline & 6 & $\begin{array}{l}\text { Have you been able to appeal the } \\
\text { (outcome) arrived at by those } \\
\text { procedures? }\end{array}$ & 0.764 & 0.032 & 0.763 & 24.118 & 0.000 \\
\hline & 7 & $\begin{array}{l}\text { Have those procedures upheld ethical } \\
\text { and moral standards? }\end{array}$ & 0.753 & 0.035 & 0.753 & 21.486 & 0.000 \\
\hline \multirow{4}{*}{$\begin{array}{l}\text { b)Distributive } \\
\text { Justice }\end{array}$} & 1 & $\begin{array}{l}\text { Does your (outcome) reflect the } \\
\text { effort you have put into your work? }\end{array}$ & 0.819 & 0.024 & 0.820 & 34.272 & 0.000 \\
\hline & 2 & $\begin{array}{l}\text { Is your (outcome) appropriate for the } \\
\text { work you have completed? }\end{array}$ & 0.754 & 0.039 & 0.755 & 19.343 & 0.000 \\
\hline & 3 & $\begin{array}{l}\text { Does your (outcome) reflect what } \\
\text { you have contributed to the } \\
\text { organization? }\end{array}$ & 0.801 & 0.030 & 0.801 & 26.802 & 0.000 \\
\hline & 4 & $\begin{array}{l}\text { Is your (outcome) justified, given } \\
\text { your performance? }\end{array}$ & 0.825 & 0.024 & 0.828 & 34.204 & 0.000 \\
\hline \multirow{9}{*}{$\begin{array}{l}\text { c)Interactional } \\
\text { Justice }\end{array}$} & 1 & $\begin{array}{l}\text { Has (he/she) treated you in a polite } \\
\text { manner? }\end{array}$ & 0.771 & 0.029 & 0.775 & 26.678 & 0.000 \\
\hline & 2 & $\begin{array}{l}\text { Has (he/she) treated you with } \\
\text { dignity? }\end{array}$ & 0.807 & 0.031 & 0.808 & 25.976 & 0.000 \\
\hline & 3 & $\begin{array}{l}\text { Has (he/she) treated you with } \\
\text { respect? }\end{array}$ & 0.808 & 0.023 & 0.809 & 34.652 & 0.000 \\
\hline & 4 & $\begin{array}{l}\text { Has (he/she) refrained from improper } \\
\text { remarks or comments? }\end{array}$ & 0.750 & 0.039 & 0.751 & 19.221 & 0.000 \\
\hline & 5 & $\begin{array}{l}\text { Has (he/she) been candid in (his/her) } \\
\text { communications with you? }\end{array}$ & 0.803 & 0.026 & 0.804 & 30.923 & 0.000 \\
\hline & 6 & $\begin{array}{l}\text { Has (he/she) explained the } \\
\text { procedures thoroughly? }\end{array}$ & 0.803 & 0.027 & 0.803 & 29.594 & 0.000 \\
\hline & 7 & $\begin{array}{l}\text { Were (his/her) explanations } \\
\text { regarding the procedures reasonable? }\end{array}$ & 0.773 & 0.033 & 0.774 & 23.787 & 0.000 \\
\hline & 8 & $\begin{array}{l}\text { Has (he/she) communicated details in } \\
\text { a timely manner? }\end{array}$ & 0.799 & 0.025 & 0.798 & 31.603 & 0.000 \\
\hline & 9 & $\begin{array}{l}\text { Has (he/she) seemed to tailor } \\
\text { (his/her) communications to } \\
\text { individuals' specific needs? }\end{array}$ & 0.813 & 0.023 & 0.813 & 35.023 & 0.000 \\
\hline
\end{tabular}

Source: Own research work processed in PLS-SEM. 


\section{Macrothink}

Table no. 2 of Descriptive Statistics indicates that the items linked to independent variable Ethical Leadership mean scores lie under the range of $0.491-0.813$ while the standard deviation lies between $0.030-0.080$. Items related to dependent variable Interpersonal Citizenship Behavior (OCBI) have mean scores of $0.601-0.805$ whereas the standard deviation of these items lies between the range of $0.025-0.049$. There are twenty items of four sub-variables (i.e. empathic concern, common humanity, kindness, and mindfulness) of mediating variable Workplace Compassion were included in the questionnaire but only fifteen items have significant values in this research and remaining five items excluded because of their insignificant values. The mean values of these fifteen items of mediating variable workplace compassion lie between the range of $0.554-0.878$ while standard deviation values range from $0.024-0.091$. Another mediating variable Organizational Justice consist of four sub-variables which includes a total of twenty items and their mean scores lies between the range of $0.663-0.825$ whereas standard deviation ranges between $0.023-0.063$. Descriptive statistics score of all other variables of the study also demonstrate that the majority of respondents believe and agree that Ethical Leadership, Interpersonal Organizational Citizenship behavior (OCBI), factors of Workplace Compassion (i.e. empathic concern, common humanity, mindfulness and kindness), and Organizational Justice factors (i.e. procedural justice, distributive justice and interactional justice) have significant relationship as P-value of each item is less than 0.001 .

\subsection{Structural Equation Modeling}

To evaluate the generated hypothesis of the study, we used the Structural Equation Model (SEM) while the experiments performed using Smart PLS software. Besides, all the study designs test for indirect and direct effects. The approach used under distinct models and methods of regression (Barron \& Kenny, 1986) is the Structural Equation Model (SEM). It is used to quantify the structural relationship between exogenous and endogenous variables. Factor analysis and multivariate analysis are part of this. Furthermore, to evaluate the causes and effects of the relationship, the regression equation attempts to establish each construct, although all variables in the causal model can determine the causes and impact of the exact moment. Similarly, the purpose of using such a model means that a bootstrapping strategy applied has deemed acceptable for both large and small sample sizes and does not require any kind an indirect influence (Hayes, 2013).

\subsubsection{Measurement of Outer Model}

The aim of measuring fit in the measuring model is to investigate the instrument's reliability and validity to check its consistency and rationality. In the Smart PLS software, we use convergent validity and discriminatory validity test.

Composite Reliability:

Reliability refers to the stability of the outcomes of the questionnaire. In the case of a similar target group, the questionnaire would provide similar results at every stage the questioner re-uses. It indicates that the survey's internal accuracy and repeatability are high. Maintaining a strategic distance from discrimination in research is the strongest indicator of unwavering 


\section{NI Macrothink}

Global Journal of Educational Studies

ISSN 2377-3936

2021, Vol. 7, No. 2

progress. In this way, by conducting follow-up and investigation tests, using several methods of study and review by different researchers, it continues to be developed. The reliability and reputation of the discovery process are also involved in this. Using a composite measure of reliability, the reliability of measuring instruments is measured. All values were beyond the threshold value that was widely used, i.e. 0.70.0.0. This is the reliability range of attributes agreed upon. The reliability estimate is made; by the degree of constancy among the variables (Hair, 2010). A table of composite reliability tests given below:

Table 3. Composite reliability

\begin{tabular}{|l|c|}
\hline Variables & Composite Reliability \\
\hline Ethical Leadership & 0.902 \\
\hline Interpersonal Citizenship Behavior (OCBI) & 0.885 \\
\hline Empathic Concern & 0.778 \\
\hline Common Humanity & 0.848 \\
\hline Mindfulness & 0.895 \\
\hline Kindness & 0.879 \\
\hline Procedural Justice & 0.883 \\
\hline Distributive justice & 0.878 \\
\hline Interactional Justice & 0.938 \\
\hline
\end{tabular}

Source: Own research work processed in PLS-SEM.

\section{$\underline{\text { Factor Loadings Significant: }}$}

The items used throughout the Confirmatory Factor Analysis (CFA); were also included in the descriptive statistics table. High loading variables are considered to be constructed with loading of 0.5 , while constructions with below loading of 0.5 , are found less likely to be excluded from the table.

\section{Convergent Validity:}

For at least two similar construction measures (Carmines \& Zeller, 1979), the degree of agreement is of convergent validity. The convergent validity is measured; for each factor through the inspection of the collected variance (Fornell \& Larcker, 1981). Discussing to Fornell and Larcker (1981), the convergent validity is determined; when the derived value of AVE is more than 0.5 , and the outcome is that the loadings are appropriate, but less than 0.5 is considered less effective for the sample.

The outcome is shown in the following table. 
Table 4. Reliability \& Validity

\begin{tabular}{|l|l|l|l|}
\hline Variables & $\begin{array}{l}\text { Cronbach's } \\
\text { Alpha }\end{array}$ & $\begin{array}{l}\text { Composite } \\
\text { Reliability }\end{array}$ & $\begin{array}{l}\text { Average Variance } \\
\text { Extracted (AVE) }\end{array}$ \\
\hline Ethical Leadership & 0.879 & 0.902 & 0.482 \\
\hline Interpersonal Citizenship Behavior (OCBI) & 0.848 & 0.885 & 0.526 \\
\hline Empathic Concern & 0.620 & 0.778 & 0.472 \\
\hline Common Humanity & 0.764 & 0.848 & 0.583 \\
\hline Mindfulness & 0.825 & 0.895 & 0.741 \\
\hline Kindness & 0.817 & 0.879 & 0.645 \\
\hline Procedural Justice & 0.847 & 0.857 & 0.519 \\
\hline Distributive justice & 0.815 & 0.878 & 0.642 \\
\hline Interactional Justice & 0.926 & 0.938 & 0.629 \\
\hline
\end{tabular}

Source: Own research work processed in PLS-SEM.

\section{Discriminant Validity:}

It is possible to define discriminatory validity as an individual hypothesis if it differs from some other concepts in the model (Carmines \& Zeller, 1979). Discriminate validity results are appropriate when hypotheses have more than 0.5 AVE loading, which means at least 50 percent of variance taken from the construction (Chin, 1998). Discriminate validity was determined when the elements of the diagonal in the parallel rows and columns are considerably greater than those in the off-diagonal. Discriminant validity examinations are doing to see whether non-related hypotheses or dimensions are easily unrelated or not. An appropriate discriminatory validity assessment demonstrates that an idea's trial is not unusually associated wth different tests intended to test hypothetically different concepts. The table of discriminant validity is given below:

Table 5. Fornell-Larcker Criterion

\begin{tabular}{|l|l|l|l|l|l|l|l|l|l|}
\hline Variables & CH & DJ & EC & EL & IJ & OCBI & K & M & PJ \\
\hline Common Humanity (CH) & 0.764 & & & & & & & & \\
\hline Distributive justice (DJ) & 0.333 & 0.801 & & & & & & & \\
\hline Empathic Concern (EC) & 0.515 & 0.395 & 0.687 & & & & & & \\
\hline Ethical Leadership (EL) & 0.122 & 0.208 & 0.191 & 0.694 & & & & & \\
\hline Interactional Justice (IJ) & 0.293 & 0.585 & 0.356 & 0.278 & 0.793 & & & & \\
\hline $\begin{array}{l}\text { Interpersonal Citizenship } \\
\text { Behavior (OCBI) }\end{array}$ & 0.305 & 0.390 & 0.503 & 0.361 & 0.402 & 0.725 & & & \\
\hline Kindness (K) & 0.619 & 0.492 & 0.508 & 0.200 & 0.422 & 0.426 & 0.803 & & \\
\hline Mindfulness (M) & 0.001 & -0.059 & -0.006 & -0.146 & -0.064 & -0.080 & -0.201 & 0.861 & \\
\hline Procedural Justice (PJ) & 0.370 & 0.590 & 0.390 & 0.221 & 0.673 & 0.365 & 0.442 & 0.003 & 0.720 \\
\hline
\end{tabular}

Source: Own research work processed in PLS-SEM. 


\section{MIMacrothink}

Model Fit Measures:

Several issues, such as the standardized root-mean-square residual (SRMR) and the identical model fit as d ULS and d G, the Normed Fit Index ( NFI) and x2 (Chi-square), determine the model's fitness in SEM-PLS. Model fit measurements consisting of both the saturated model and the predicted model's measured values are showing in the table. The saturated model measures the relationship of all hypotheses. On the other side, the proposed model assesses the model structure into consideration and has based upon the total effect scheme.

Table 6. Fit Summary

\begin{tabular}{|l|l|l|}
\hline & Saturated Model & Estimated Model \\
\hline SRMR & 0.062 & 0.167 \\
\hline d_ULS & 5.356 & 38.244 \\
\hline d_G & 1.621 & 2.184 \\
\hline Chi-Square & 3114.005 & 3855.445 \\
\hline NFI & 0.697 & 0.624 \\
\hline
\end{tabular}

Source: Own research work processed in PLS-SEM.

\section{The Structural Model (Inner Model) and Hypotheses Testing:}

The structural model helps to understand and analyses the complex relations of the variables, Marko and Jun-Hwa (2019). The structural model was also tested and worked on the SmartPLS version 3.2.3 (Ringle, Wende, \& Becker, 2015). Moreover, the structural model was running through bootstrapping (Efronand, 1968; Haenlien \& Kaplan, 2004). The snapshot of the result after running the test is attached below, along with the interpretation of the outcome.

The bootstrapping test is one of the key steps in the PLS-SEM, which provides data in the constancy of the guess time factor. In this method, sub-tests are taken from the first instance anywhere, including substitution (Hair, Matthews, Matthews, \& Sarstedt, 2017). The Stability evidence for coefficient calculation; is given by Bootstrapping. In this approach, the initial replacement sample is taking from the large no. of sub-samples (Hair et al., 2016). The SmartPLS shows the t-values for the structural model estimates obtained from the bootstrap process, after running the bootstrap routine. In the table below, the results of the path coefficients for all the hypotheses are showed. The t-value greater than $1.96(\mathrm{p}<.005)$ suggests that at 95 percent of the confidence level, the relationship is significant $(5-007=$ 0.05). The Paths which indicate whether the relation between measurable and latent variables is meaningful or not.The diagram of the direction, as shown in Figure 2. 


\section{Macrothink}

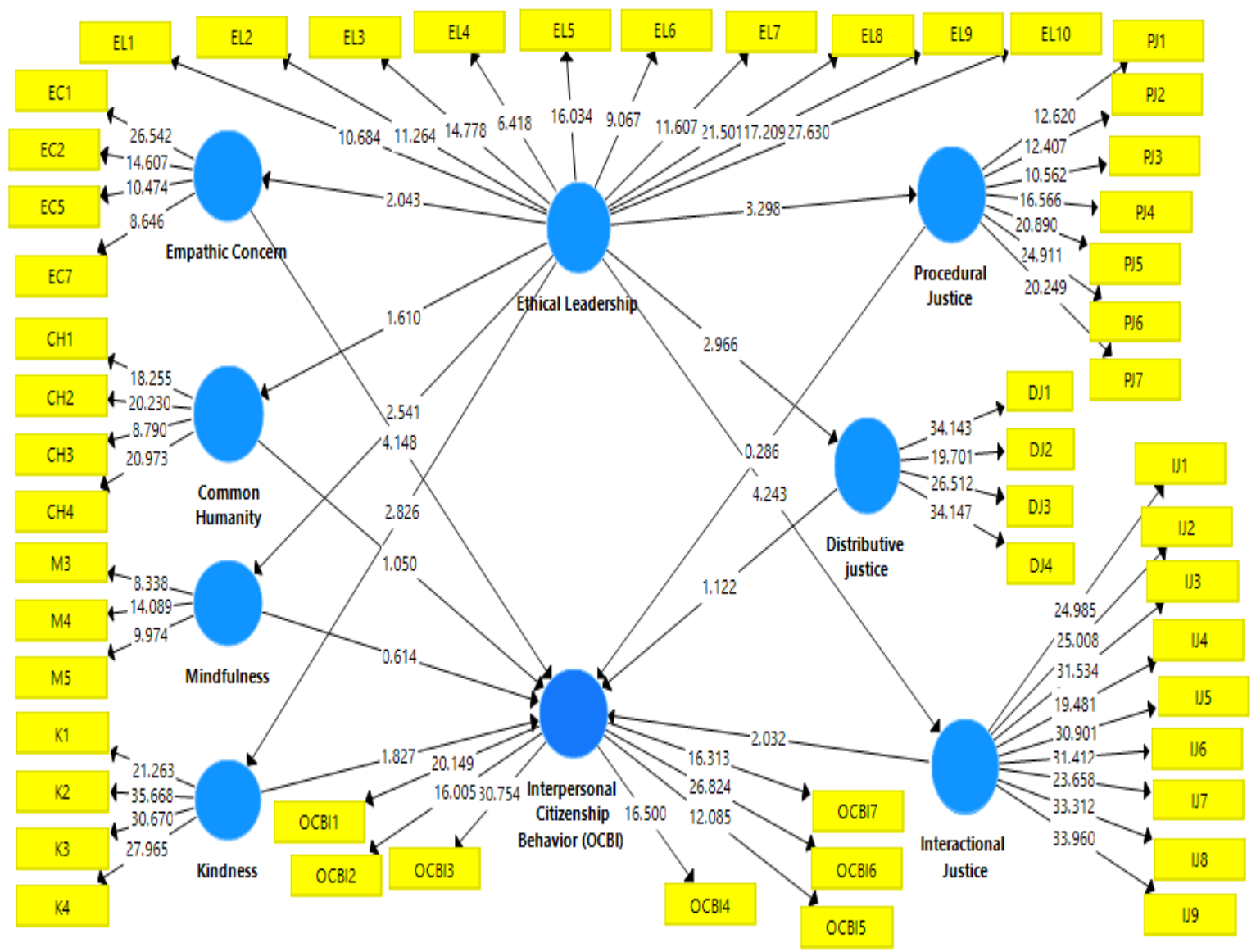

Figure 2. PLS-Bootstrapping

Source: Own research work processed in PLS-SEM.

Ethical leadership included in the study model as an independent variable with Workplace Compassion (Empathic Concern, Common Humanity, Mindfulness, and Kindness) and Organizational Justice (Procedural Justice, Distributive Justice \& Interactional Justice) as mediators and Interpersonal Citizenship Behavior (OCBI) as a dependent variable. Specifically, this model tests whether the direct impact of ethical leadership on these mediators is significant and whether mediators must have an indirect effect of ethical leadership on interpersonal citizenship behavior (OCBI). 


\subsection{Direct Effect}

Table 7. Direct effect

\begin{tabular}{|c|c|c|c|c|c|}
\hline Hyp. & Structural Path & $\begin{array}{l}\text { Path } \\
\text { Coefficients }\end{array}$ & T-values & P-values & $\begin{array}{l}\text { Decision } \\
\left(\mathbf{H}_{\mathbf{a}}\right) \\
\end{array}$ \\
\hline H1a & Ethical Leadership -> Empathic Concern & 0.191 & 2.109 & 0.035 & Accepted \\
\hline $\mathrm{H} 1 \mathrm{~b}$ & Ethical Leadership -> Common Humanity & 0.122 & 1.667 & 0.096 & Rejected \\
\hline H1c & Ethical Leadership -> Mindfulness & -0.146 & 2.406 & 0.016 & Accepted \\
\hline H1d & Ethical Leadership -> Kindness & 0.200 & 2.854 & 0.005 & Accepted \\
\hline $\mathrm{H} 2 \mathrm{a}$ & Ethical Leadership -> Procedural Justice & 0.221 & 3.375 & 0.001 & Accepted \\
\hline $\mathrm{H} 2 \mathrm{~b}$ & Ethical Leadership -> Distributive justice & 0.208 & 3.210 & 0.001 & Accepted \\
\hline $\mathrm{H} 2 \mathrm{c}$ & Ethical Leadership -> Interactional Justice & 0.278 & 4.216 & 0.000 & Accepted \\
\hline $\mathrm{H} 3 \mathrm{a}$ & $\begin{array}{l}\text { Empathic Concern -> Interpersonal Citizenship } \\
\text { Behavior (OCBI) }\end{array}$ & 0.354 & 4.287 & 0.000 & Accepted \\
\hline $\mathrm{H} 3 \mathrm{~b}$ & $\begin{array}{l}\text { Common Humanity -> Interpersonal Citizenship } \\
\text { Behavior (OCBI) }\end{array}$ & -0.058 & 0.996 & 0.320 & Rejected \\
\hline $\mathrm{H} 3 \mathrm{c}$ & $\begin{array}{l}\text { Mindfulness -> Interpersonal Citizenship Behavior } \\
(\mathrm{OCBI})\end{array}$ & -0.031 & 0.560 & 0.576 & Rejected \\
\hline $\mathrm{H} 3 \mathrm{~d}$ & $\begin{array}{l}\text { Kindness } \rightarrow \text { Interpersonal Citizenship Behavior } \\
(\mathrm{OCBI})\end{array}$ & 0.157 & 1.794 & 0.073 & Rejected \\
\hline $\mathrm{H} 4 \mathrm{a}$ & $\begin{array}{l}\text { Procedural Justice } \rightarrow \text { Interpersonal Citizenship } \\
\text { Behavior (OCBI) }\end{array}$ & 0.021 & 0.283 & 0.777 & Rejected \\
\hline $\mathrm{H} 4 \mathrm{~b}$ & $\begin{array}{l}\text { Distributive justice } \rightarrow \text { Interpersonal Citizenship } \\
\text { Behavior (OCBI) }\end{array}$ & 0.083 & 1.065 & 0.288 & Rejected \\
\hline $\mathrm{H} 4 \mathrm{c}$ & $\begin{array}{l}\text { Interactional Justice -> Interpersonal Citizenship } \\
\text { Behavior (OCBI) }\end{array}$ & 0.162 & 2.077 & 0.038 & Accepted \\
\hline
\end{tabular}

Source: Own research work processed in PLS-SEM.

The above table indicates the direct effect of dependent and independent variables, Interpersonal Citizenship Behavior (OCBI), and Ethical Leadership, respectively, on the mediators. The findings show that ethical leadership is strongly and positively link to all factors of compassion in the workplace (empathic concern, mindfulness, and kindness) as well as all factors of organizational justice (procedural justice, distributive justice, and interactional justice) except for common humanity. However, ethical leadership seems to affect the Mindfulness factor negatively. Moreover, among compassion determinants, only Empathic Concern seems to affect OCBI. Whereas, only interactional justice has a significant positive association with OCB.

\subsection{Mediation Analysis}

According to the recommendation of Williams, Vandenberg, and Edwards (2009), the 
intervention or mediation impact can culminate when the product of the way between the Exogenous variable and the mediator (named as the path a) and the way between the mediator and endogenous variable (named as path b) are significant statistically (Base paper). Through the involvement of the third illustrative mediator variable, the mediation study measured the cause and effect relationship between an independent and dependent variable (Hair et al., 2016). The approach of bootstrapping is appropriate for mediation investigation in the light of fact; that it makes no supposition about the sampling division of statistics and can apply to be small sample sizes (Hair et al., 2016). In PLS-SEM, to draw the mediation analysis, the initial step is to evaluate the direct or immediate impact of independent variables on the endogenous variable, which ought to be significant if the mediator is not involved (Zhao, Lynch, \& Chen, 2010).

Below is the table of Specific Indirect Effects showing the result of the mediating effects?

Table 8. Specific indirect effect

\begin{tabular}{|l|l|l|l|l|l|}
\hline Hyp. & Structural Path & $\begin{array}{l}\text { Path } \\
\text { Coefficients }\end{array}$ & T-values & P-values & Decision \\
\hline H5a & $\begin{array}{l}\text { Ethical Leadership -> Empathic Concern -> } \\
\text { Interpersonal Citizenship Behavior (OCBI) }\end{array}$ & 0.068 & 1.539 & 0.124 & Rejected \\
\hline H5b & $\begin{array}{l}\text { Ethical Leadership -> Common Humanity -> } \\
\text { Interpersonal Citizenship Behavior (OCBI) }\end{array}$ & -0.007 & 0.786 & 0.432 & Rejected \\
\hline H5c & $\begin{array}{l}\text { Ethical Leadership -> Mindfulness Interpersonal } \\
\text { Citizenship Behavior (OCBI) }\end{array}$ & 0.005 & 0.460 & 0.646 & Rejected \\
\hline H5d & $\begin{array}{l}\text { Ethical Leadership -> Kindness -> Interpersonal } \\
\text { Citizenship Behavior (OCBI) }\end{array}$ & 0.031 & 1.178 & 0.239 & Rejected \\
\hline H6a & $\begin{array}{l}\text { Ethical Leadership -> Procedural Justice -> Interpersonal } \\
\text { Citizenship Behavior (OCBI) }\end{array}$ & 0.005 & 0.257 & 0.798 & Rejected \\
\hline H6b & $\begin{array}{l}\text { Ethical Leadership -> Distributive justice -> } \\
\text { Interpersonal Citizenship Behavior (OCBI) }\end{array}$ & 0.017 & 0.817 & 0.415 & Rejected \\
\hline H6c & $\begin{array}{l}\text { Ethical Leadership -> Interactional Justice >> } \\
\text { Interpersonal Citizenship Behavior (OCBI) }\end{array}$ & 0.045 & 1.609 & 0.108 & Rejected \\
\hline
\end{tabular}

Source: Own research work processed in PLS-SEM.

The indirect effect of all mediators in the association between Ethical Leadership and Interpersonal Citizenship Behavior (OCBI) rejected because their t-values are less than 1.96, and p-values are more than 0.05. Hence, the hypothesis that Workplace Compassion and Organizational Justice are substantial mediators in the association of ethical leadership and OCBI. 


\section{Macrothink}

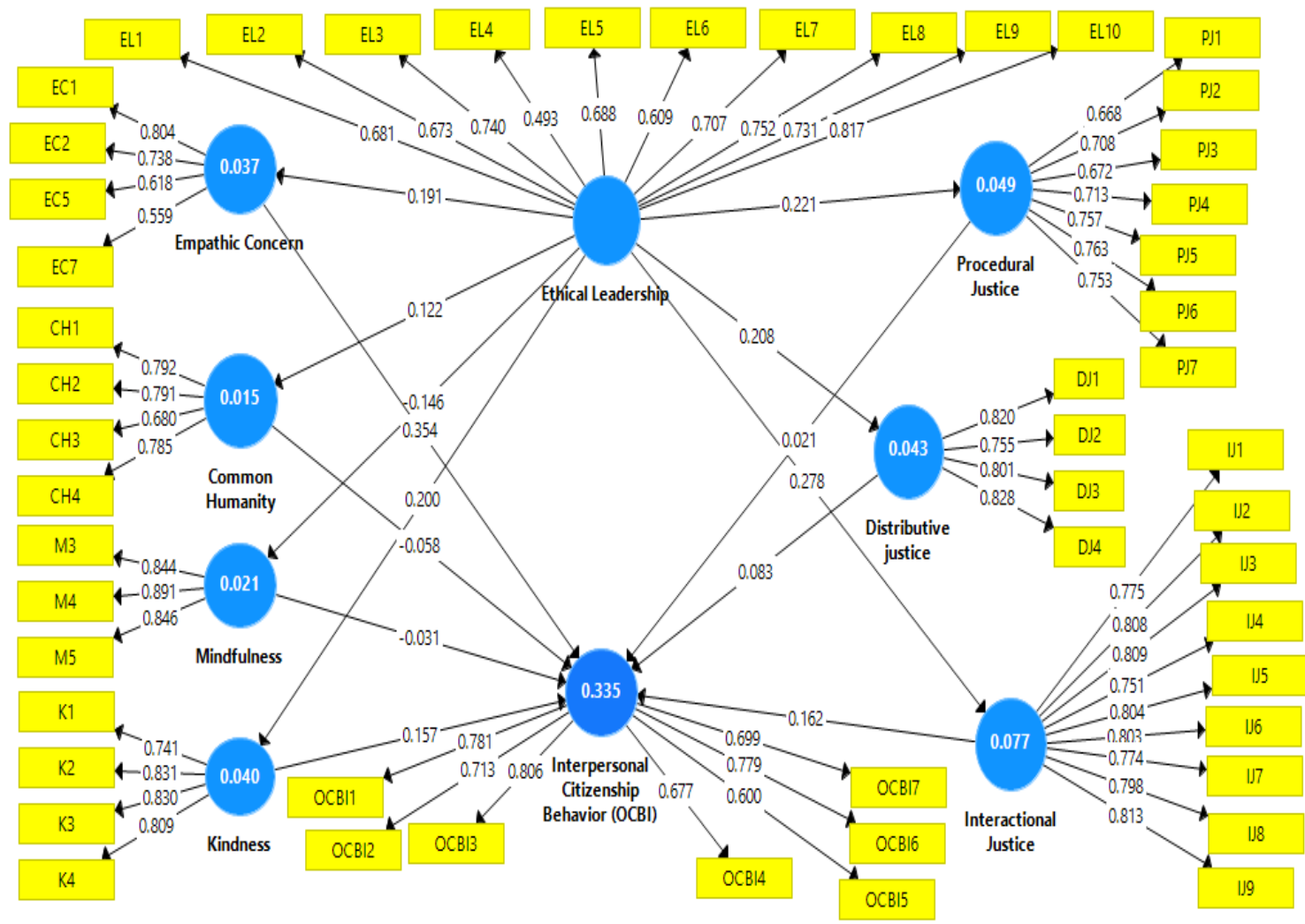

Figure 2. PLS-Algorithm

Source: Own research work processed in PLS-SEM.

\section{Discussion}

Findings of an investigation contribute to the creation of the discussion towards the effects of ethical leadership on the ethical behaviors of followers and justice perceptions. The study draws the following results, firstly, all factors of workplace compassion and organizational justice were positively and significantly predicted by ethical leadership except Common Humanity; moreover, ethical leadership seems to affect the Mindfulness factor negatively. Secondly, among compassion determinants, only Empathic Concern seems to affect OCBI, and only interactional justice shows a significant and positive association with OCBI. Finally, among the relationship between ethical leadership and OCBI, there would be an unimportant mediating influence of workplace compassion and organizational justice. Besides, research findings have shown that superiors who behave more ethically can move their followers to be aware of peer difficulties and take action to reduce or eliminate their comfort, in the form of interpersonal OCBs.

Several earlier research studies have centered on the attitudes and behavioral responses of followers to ethical leadership that could potentially benefit their colleagues, such as pro-social actions, group engagement, job satisfaction, and reduced counter-productive actions between others (e.g., Kim \& Brymer, 2011; Mayer et al., 2012; Neubert et al., 2009; 
Zhu et al., 2004). Outcomes of the investigation as fit and match as well with the findings of Kalshoven et al. (2013) that the workgroup's mutual ideas of moral consciousness and empathic concern act like mediators in the association amid ethical leadership and advocacy and followers' courteousness. As mentioned in this article, the mediating role of compassion will provide useful insights for business leaders to understand the role that cultural norms and social imbalances will play in helping workplace peers. Furthermore, the role of the mediator, corporate justice helps to establish continuity in the workplace and also encourages a moral organizational culture. The ethical working environment allows managers and staff to work for the achievement of the organization's objectives.

Contrarily to expectations, the findings rejected influences of occupational compassion (empathic consideration, shared humanity, mindfulness, and kindness) as well as organizational justice (procedural justice, distributive justice, and interactive justice) as mediators in the relationship between ethical leadership and interpersonal citizenship behaviors (OCBI). The difficulty of this so-called psychological versatility in the stage of compassion is the one way of understanding why mindfulness unable to mediate an ethical leadership citizenship relation. Instead of being a part of the compassionate phase, Tirch (2010) recognized that mindfulness tends to lubricate the sub-processes of compassion (i.e., observing, experiencing, and responding). As such, by reducing the sense of immediate reaction and danger or by improving self-regulation, mindfulness can influence the compassion of employees (Atkins \& Parker, 2012).

Mindfulness, though, not compassionate itself because, apart from compassion, it may be present in a different person and organizational processes. For instance, Dane (2011) noted, it was possible to connect mindfulness and positive means of task success. This connection indicates that, instead of showing only concern, mindfulness can further receive benefit from the psychological versatility of employees in increasing the task's effectiveness (Dane, 2011). Empathy or insightful comments about others are not synonymous with ethical leadership at the end of the day, proposing that moral choices include as much as positive or negative choices about others. These approaches will show why, as mediators, empathic concern, common humanity, mindfulness, and kindness have suffered.

Further, the research study did not support the variables of organizational justice as intermediaries in ethical leadership's association with OCBI; This shows that people are not satisfied with the framework of their organizations, and they also do not have much interaction with their Employer or Manager that resulted in a negative relationship with OCB. Moreover, the results of the current study are opposed to previous studies which indicate, if there is a positive leadership within the organization, then employees would have positive outcomes (Avey, Hughes, Norman, \& Luthans, 2008; Jong \& Hartog, 2007; Avey, Hughes, Norman \& Luthans, 2008; Fong \& Snape, 2015; Nelson, 2014).

Conclusively, the results of both of them did not support the proposed hypothesis that workplace compassion and organizational justice do not mediate favorably and substantially in the association between ethical leadership with OCBI. Data obtained; via the sampling technique of non-probability. To analyze the questionnaire answers, descriptive statistics; and 
Structural Equation Modeling (SEM), was used for the research.

\section{Conclusion}

The purpose of the current study is to explore the influence of ethical leadership on interpersonal citizenship behaviors (OCBI) through mediating effects of compassion and organizational justice in the workplace. Data were obtained from 350 employees employed in various divisions operating in Pakistan. This study evaluated a total of 6 hypotheses, 4 of which were direct hypotheses and 2 were indirect hypotheses. To assess the hypotheses of the study, Structural Equation Model (SEM) has been used, while experiments were carried out using Smart PLS software.

This research intends to extend our recognition of the ethical leadership in organizational contexts by exploring whether the factors of workplace compassion (i.e. empathic care, shared humanity, mindfulness, and kindness) and the dimensions of organizational justice (i.e. procedural justice, distributive justice, and interactional justice) serve as mediators in an association among ethical leadership and OCBI. To achieve this objective, we investigated whether ethical leadership influences compassionate feelings and offers empirical support that is distinct from all the variables used in this analysis. In the end, the analysis looked at the theoretical and administrative recommendations of the decisions.

This research leads to a greater awareness of the effect of ethical leadership on interpersonal citizenship behavior (OCBI) management performance. Previous research on the effects of ethical leadership on citizenship actions has not yet created trends that fully clarify the part that compassion plays in these relationships. Further, this research examined, when executives link to employees that they desire to recognized ethical leaders, they allow their workers to deal with OCBs based on workers. This research contributes greatly to this section of the literature on ethical leadership, compassion, and organizational justice by promoting the mediating role of workplace compassion and organizational justice. More notably, the study reveals that not only the quid-pro-quo responses of the workers of future ethical leadership but also fundamentally and ethically motivated responses focused on compassion and justice.

\subsection{Implication}

For each organization, the involvement of ethical leadership is needed to maximize individual and group-based effectiveness. Further, the involvement of ethical leadership assures that corporate justice and workplace compassion are adequately exercised in the company. By doing so, ethical leaders will help promote individual work results (Brown et al., 2005). A coherent structure for understanding the role or importance of ethical leadership and its connection with employee results is provided by the decision of the current study, taking these factors into account. Furthermore, the mediating role of workplace compassion and organizational justice benefits human resource managers by making proper use of the different aspects of organizational justice and compassionate variables that can improve employee results and activities that are likely to occur in the workplace. Since the theoretical recommendations of the current study are considered, the current study's decisions clarify the 
function and significance of ethical leadership in influencing the actions of the employee by taking compassion and corporate justice as a mediating variable in the workplace.

It is also suggested that the value and efficacy of ethical leadership should be realized by corporate leaders. Ethical leadership is the primary and leading role in fostering compassion at the workplace and developing the fairness of workers in the company. Which in exchange, creates a stronger understanding and link between employees, fairness, as well as anticipation of supporting and showing concern to employees or peers in need. The justice environment should also be introduced in companies to enhance the actions of workers in terms of corporate citizenship and grow the tangible and intangible interests of the organization.

This research will provide insight into the management of organizations running in Pakistan that by proving fairness and justice perceptions to the workers, they can improve the overall effectiveness of the organizations. This study will not only present benefit to the organizations but also raise the well-being of its employees and also affects the employees' perception concerning their workplace.

\section{References}

Alexander \& Ruderman. (1987). The role of procedural and distributive justice in organizational behavior. Social Justice Research. https://doi.org/10.1007/BF01048015

Ambrose. (2002). Sabotage in the workplace: The role of organizational justice. Organizational Behavior and Human Decision Processes, 89, 947-965. https://doi.org/10.1016/S0749-5978(02)00037-7

Ambrose \& Arnaud. (2005). Are procedural justice and distributive justice conceptually distinct? In J. Greenberg \& J. A. Colquitt (Eds.), Handbook of organizational justice (pp. 59-84). Mahwah, NJ: Erlbaum.

Ambrose, Hess, \& Ganesan. (2007). The relationship between justice and attitudes: An examination of justice effects on event and system-related attitudes. Organizational Behavior and Human Decision Processes, 103, 21-36. https://doi.org/10.1016/j.obhdp.2007.01.001

Anderson \& Williams. (1996). Interpersonal, job, and individual factors related to helping processes at work. Journal of Applied Psychology, 81(3), 282-296. https://doi.org/10.1037/0021-9010.81.3.282

Andersson \& Bateman. (1997). Cynicism in the workplace: Some causes and effects. Journal of Organizational Behavior, 18(5), 449-469. https://doi.org/10.1002/(SICI)1099-1379(199709)18:5<449::AID-JOB808>3.0.CO;2-O

Angelidis \& Nabil. (2011). The impact of emotional intelligence on the ethical judgment of managers. Journal of Business Ethics, 99(1), 111-119. https://doi.org/10.1007/s10551-011-1158-5

Ashforth. (2000). All in a day's work: Boundaries and micro role transitions. Academy of Management Review, 25(3), 472-491. https://doi.org/10.2307/259305 
Atkins \& Parker. (2012). Understanding individual compassion in organizations: The role of appraisals and psychological flexibility. Academy of Management Review, 37(4), 524-546. https://doi.org/10.5465/amr.2010.0490

Avey, Hughes, Norman, \& Luthans. (2008). Using positivity, transformational leadership and empowerment to combat employee negativity. Leadership and Organization Development Journal, 29(1-2), 110-126. https://doi.org/10.1108/01437730810852470

Avey. (2011). When leadership goes unnoticed: The moderating role of follower selfesteem on the relationship between ethical leadership and follower behavior. Journal of Business Ethics, 98(4), 573-582. https://doi.org/10.1007/s10551-010-0610-2

Avey, Wernsing, \& Palanski. (2012). Exploring the process of ethical leadership: The mediating role of employee voice and psychological ownership. Journal of Business Ethics, 107(1), 21-34. https://doi.org/10.1007/s10551-012-1298-2

Avolio, Walumbwa, \& Weber. (2009). Leadership: Current theories, research, and future directions. Annual Review of Psychology, 60, 421-449. https://doi.org/10.1146/annurev.psych.60.110707.163621

Bal, de Lange, Ybema, Jansen, \& van der Velde. (2011). Age and trust as moderators in the relation between procedural justice and turnover: A large - scale longitudinal study. Applied Psychology, 60(1), 66-86. https://doi.org/10.1111/j.1464-0597.2010.00427.x

Bandura. (1977). Self-efficacy: Toward a unifying theory of behavioral change. Psychological Review, 84, 191-215. https://doi.org/10.1037/0033-295X.84.2.191

Bandura. (1986). Social foundations of thought and action: A social cognitive theory. Englewood Cliffs, NJ: Prentice Hall.

Bandura. (1999). Moral disengagement in the perpetration of inhumanities. Personality and Social Psychology Review, 3, 193-209. https://doi.org/10.1207/s15327957pspr0303_3

Bass. (1990). Bass and Stogdill's handbook of leadership: Theory, research, and managerial applications. New York, NY: Free Press.

Bass. (1999). Two decades of research and development in transformational leadership. European Journal of Work \& Organizational Psychology, 8(1), 9-32. https://doi.org/10.1080/135943299398410

Bateman \& Organ. (1983). Job Satisfaction and the Good Soldier: The Relationship between Affect and Employee. The Academy of Management Journal. https://doi.org/10.2307/255908

Batson. (1994). Why act for the public good? Four answers. Personality and Social Psychology Bulletin, 20(5), 603-610. https://doi.org/10.1177/0146167294205016

Batson \& Ahmad. (2009). Using empathy to improve intergroup attitudes and relations. Social Issues and Policy Review, 3(1), 141-177. https://doi.org/10.1111/j.1751-2409.2009.01013.x 
Bennett-Goleman. (2001). Emotional alchemy: How the mind can heal the heart. New York: Three Rivers Press.

Bies \& Moag, J. S. (1986). Interactional justice: Communication criteria of fairness. In R. J. Lewicki, B. H. Sheppard, \& M. H. Bazerman (Eds.), Research on negotiation in organizations (pp. 43-55). Greenwich, CT: JAI Press.

Bies. (1987). Interactional fairness judgments: The influence of causal accounts. Social Justice Research, 1, 199-218. https://doi.org/10.1007/BF01048016

Bies. (2001). Interactional (in)justice: The sacred and the profane. In J. Greenberg \& R. Cropanzano (Eds.), Advances in organizational justice (pp. 89-118). Stanford, CA: Stanford University Press.

Black. (2012). Psychometric assessment of the mindful attention awareness scale (MAAS) among Chinese adolescents. Assessment, 19(1), 42-52. https://doi.org/10.1177/1073191111415365

Blau, P. M. (1964). Exchange and power in social life. New York: Academic Press.

Bobocel. (1999a). Are interactional justice and procedural justice different? Framing the debate. Paper presented at the International Roundtable on Innovations in Organizational Justice Research, Nice, France.

Boehm \& Dwertmann. (2015). Forging a single-edged sword: Facilitating positive age and disability diversity effects in the workplace through leadership, positive climates, and HR practices. Work, Aging and Retirement, 1(1), 41-63. https://doi.org/10.1093/workar/wau008

Borman \& Motowidlo. (1993). Expanding the criterion domain to include elements of contextual performance (p. 71). San Francisco: Jossey-Bass, Personnel Selection in Organizations.

Bowler \& Brass. (2006). Relational correlated of interpersonal citizenship behavior: A social network perspective. Journal of Applied Psychology, 91(1), 70-82. https://doi.org/10.1037/0021-9010.91.1.70

Brief (2001). Collective corruption in the corporate world: Toward a process model. In M. E. Turner (Ed.), Groups at work: Theory and research (pp. 471-499). Mahwah, NJ: Lawrence Erlbaum.

Brown. (1999). Soul without shame: A guide to liberating yourself from the judge within. Boston: Shambhala Publications.

Brown, Treviño, \& Harrison. (2005). Ethical leadership: A social learning perspective for construct development and testing. Organizational Behavior and Human Decision Processes, 97(2005), 117-134. https://doi.org/10.1016/j.obhdp.2005.03.002

Brown \& Treviño. (2006). Ethical leadership: A review and future directions. The Leadership Quarterly, 17, 595-616. https://doi.org/10.1016/j.leaqua.2006.10.004 
Brown. (2007). Mindfulness: Theoretical foundations and evidence for its salutary effects. Psychological Inquiry, 18(4), 211-237. https://doi.org/10.1080/10478400701598298

Brown. (2007). Misconceptions of ethical leadership: How to avoid potential pitfalls. Organizational Dynamics, 36, 140-155. https://doi.org/10.1016/j.orgdyn.2007.03.003

Brown \& Mitchell. (2010). Ethical and unethical leadership: Exploring new avenues for future research. Business Ethics Quarterly, 20(4), 583-616. https://doi.org/10.5840/beq201020439

Brown \& Treviño. (2014). Do role models matter? An investigation of role modeling as an antecedent of perceived ethical leadership. Journal of Business Ethics, 122(4), 587-598. https://doi.org/10.1007/s10551-013-1769-0

Burton, Peachey, \& Wells (2016). The Role of Servant Leadership in Developing an Ethical Climate in Sport Organizations. Journal of Sport Management, 1-37.

Camps, Decoster, \& Stouten (2012). My share is fair, so i don't care. Journal of Personnel Psychology. https://doi.org/10.1027/1866-5888/a000058

Carmines \& Zeller. (1979). Reliability and Validity Assessment. https://doi.org/10.4135/9781412985642

Cassell. (2002). Compassion. In C. R. Snyder \& S. J. Lopez (Eds.), Handbook of positive psychology (pp. 434-445). New York: Oxford University Press.

Ciulla. (1995). Leadership ethics: Mapping the territory. Business Ethics Quarterly, 5(1), 5-28. https://doi.org/10.2307/3857269

Clark. (1997). Misery and company: Sympathy in everyday life. Chicago: The University of Chicago Press. https://doi.org/10.7208/chicago/9780226107585.001.0001

Clark. (2000). Work/family border theory: A new theory of work/family balance. Human Relations, 53(6), 747-770. https://doi.org/10.1177/0018726700536001

Clayton \& Opotow. (2003). Justice and identity: Changing perspectives on what is fair. Personality and Social Psychology Review, 7, 298-310. https://doi.org/10.1207/S15327957PSPR0704_03

Cohen-Charash, \& Spector. (2001). The role of justice in organizations: A meta-analysis. Organizational Behavior and Human Decision Processes, 86, 278-321. https://doi.org/10.1006/obhd.2001.2958

Colquitt, Conlon, Wesson, Porter, \& Ng. (2001). Justice at the millennium: a meta-analytic review of 25 years of organizational justice research. Journal of Applied Psychology, 86, 425-445. https://doi.org/10.1037/0021-9010.86.3.425

Conlon. (2005). How does organizational justice affect performance, withdrawal, and counterproductive behaviour? In J. Greenberg \& J. A. Colquitt (Eds.), Handbook of organizational justice (pp. 301-327). New Jersey: Lawrence Erlbaum. 
Cropanzano, Weiss, Suckow, \& Grandey. (2000). Doing justice to workplace emotion. In N. M. Ashkanasy, C. E. Härtel, \& W. J. Zerbe (Eds.), Emotions in the workplace: Research, theory, and practice (pp. 49-62). Quorum Books/Greenwood Publishing Group.

Cullen. (2004). Cross-national differences in managers' willingness to justify ethically suspect behaviors: A test of institutional anomie theory. Academy of Management Journal, 47(3), 411-421. https://doi.org/10.2307/20159590

Dadhich \& Bhal. (2008). Ethical leader behaviour and leader-member exchange as predictors of subordinate behaviours. Vikalpa: The Journal for Decision Makers, 33, 15-25. https://doi.org/10.1177/0256090920080402

Dane. (2011). Paying attention to mindfulness and its effects on task performance in the workplace. Journal of Management, 37(4), 997-1018. https://doi.org/10.1177/0149206310367948

Davis. (1980). A multidimensional approach to individual differences in empathy. JSAS, Catalog of Selected Documents in Psychology, 10, 85.

Davis. (1983). The effects of dispositional empathy on emotional reactions and helping: A multidimensional approach. Journal of Personality, 51(2), 167-184. https://doi.org/10.1111/j.1467-6494.1983.tb00860.x

De Cremer (2006). When authorities influence followers' affect: The interactive effect of procedural justice and transformational leadership. European Journal of Work and Organizational Psychology, 15(3), 322-351. https://doi.org/10.1080/13594320600627662

De Cremer. (2007). Emotional effects of distributive justice as a function of autocratic leader behavior. Journal of Applied Social Psychology, 37(6), 1385-1404. https://doi.org/10.1111/j.1559-1816.2007.00217.x

De Hoogh \& Den Hartog. (2008). Ethical and despotic leadership, relationships with leader's social responsibility, top management team effectiveness and subordinates' optimism: A multi-method study. The Leadership Quarterly, 19(3), 297-311. https://doi.org/10.1016/j.leaqua.2008.03.002

De Jong \& Den Hartog. (2007). How leaders influence employees' innovative behaviour. European Journal of Innovation Management, $10(1), \quad$ 41-64. https://doi.org/10.1108/14601060710720546

Dickson. (2001). An organizational climate regarding ethics: The outcome of leader values and the practices that reflect them. Leadership Quarterly, 12, 197-214. https://doi.org/10.1016/S1048-9843(01)00069-8

Diessner. (2013). Who engages with moral beauty? Journal of Moral Education, 42(2), 139-163. https://doi.org/10.1080/03057240.2013.785941

Dukerich. (2002). Beauty is in the eye of the beholder: The impact of organizational identification, identity, and image on the cooperative behaviors of physicians. Administrative 
Science Quarterly, 47(3), 507-533. https://doi.org/10.2307/3094849

Dutton \& Glynn. (2008). Positive organizational scholarship. In C. Cooper \& J. Barling (Eds.), Handbook of organizational behavior (pp. 693-712). Thousand Oaks, CA: Sage. https://doi.org/10.4135/9781849200448.n37

Dutton \& Ragins. (2007). Exploring positive relationships at work: Building a theoretical and research foundation. Mahwah, NJ: Lawrence Erlbaum

Dutton. (2007). The transformative potential of compassion at work. In D. Cooperrider, R. Fry, \& S. Piderit (Eds.), Handbook of transformative cooperation: new designs and dynamics (pp. 107-126). Palo Alto, CA: Stanford University Press.

Dutton. (2010). Pathways to positive identity construction at work: Four types of positive identity and the building of social resources. Academy of Management Review, 35(2), 265-293. https://doi.org/10.5465/AMR.2010.48463334

Eisenberg. (2000). Emotion, regulation, and moral development. Annual Review of Psychology, 51(1), 665-697. https://doi.org/10.1146/annurev.psych.51.1.665

Fein, Tziner, Lusky, \& Palachy. (2013). Relationships between ethical climate, justice perceptions, and LMX. Leadership \& Organization Development Journal, 34(2), 147-163. https://doi.org/10.1108/01437731311321913

Flynn \& Brockner. (2003). It's different to give than to receive: Predictors of givers' and receivers' reactions to favor exchange. Journal of Applied Psychology, 88(6), 1034-1045. https://doi.org/10.1037/0021-9010.88.6.1034

Folger. (2001). Fairness as deonance. In S. Gilliland, D. D. Steiner, \& D. P. Skarlicki (Eds.), Research in social issues in management (pp. 3-31). Greenwich, Mahwah, CT, NJ: Erlbaum.

Folger. (2005). What is the relationship between justice and morality. In J. Greenberg \& J. A. Colquitt (Eds.), Handbook of organizational justice (pp. 215-246). Mahwah, NJ: Erlbaum

Fong \& Snape, E. (2015). Empowering leadership, psychological empowerment and employee outcomes: Testing a multi-level mediating model. British Journal of Management, 26(1), 126-138. https://doi.org/10.1111/1467-8551.12048

Fornell \& Larcker. (1981). Evaluating structural equation models with unobservable variables and measurement error. Journal of Marketing Research. Fornell, C., \& Larcker, D. F. (1981). Evaluating structural equation models with unobservable variables and measurement error. Journal of Marketing Research. https://doi.org/10.2307/3151312

Fox, Spector, \& Miles (2001). Counterproductive work behavior (CWB) in response to job stressors and organizational justice: Some mediator and moderator tests for autonomy and emotions. Journal of Vocational Behavior, 59(3), 291-309. https://doi.org/10.1006/jvbe.2001.1803

Frost. (1999). Why compassion counts! Journal of Management Inquiry, 8(2), 127-133. https://doi.org/10.1177/105649269982004 


\section{$\Lambda$ Macrothink}

Global Journal of Educational Studies ISSN 2377-3936 2021, Vol. 7, No. 2

Frost. (2000). Narratives of compassion in organizations. In S. Fineman (Ed.), Emotion in organizations (pp. 25-45). Thousand Oaks, CA: Sage Publications.

Frost. (2003). Toxic emotions at work: How compassionate managers handle pain and conflict. Boston, MA: Harvard Business School Press.

Gillet, Fouquereau, Bonnaud-Antignac, Mokounkolo, \& Colombat. (2013). The mediating role of organizational justice in the relationship between transformational leadership and nurses' quality of work life: A cross-sectional questionnaire survey. International Journal of Nursing Studies, 50(10), 1359-1367. https://doi.org/10.1016/j.ijnurstu.2012.12.012

Gino, Moore, \& Bazerman. (2009). No harm, no foul: The outcome bias in ethical judgments. https://doi.org/10.2139/ssrn.1099464

Goetz. (2010). Compassion: An evolutionary analysis and empirical review. Psychological Bulletin, 136(3), 351. https://doi.org/10.1037/a0018807

Goldman-Schuyler. (2010). Increasing leadership integrity through mind training and embodied learning. Consulting Psychology Journal: Practice and Research, 62, 21-38. https://doi.org/10.1037/a0018081

Greenberg, J. (1990). Organizational justice: Yesterday, today, and tomorrow. Journal of Management, 16(2), 399-432. https://doi.org/10.1177/014920639001600208

Greenberg. (1990). Employee theft as a reaction to underpayment inequity: The hidden cost of pay cuts. Journal of Applied Psychology, 75, 561-568. https://doi.org/10.1037/0021-9010.75.5.561

Greenberg. (2002). Who stole the money and when? Individual and situational determinants of employee theft. Organizational Behavior and Human Decision Processes, 89, 985-1003. https://doi.org/10.1016/S0749-5978(02)00039-0

Haidt, (2006). The happiness hypothesis: Finding modern truth in ancient wisdom. New York: Basic Books.

Hair, (2010). Multivariate Data Analysis (7th ed.). Pearson.

Hair, J. F., Jr., Sarstedt, M., Matthews, L. M., \& Ringle, C. M. (2016). Identifying and treating unobserved heterogenity with FIMIX PLS: Part-1 Method. European Business Review, 28(2), 63-76. https://doi.org/10.1108/EBR-09-2015-0094

Hair, Matthews, Matthews, \& Sarstedt. (2017). PLS-SEM or CB-SEM: updated guidelines on which method to use. Int. J. Multivariate Data Analysis, 107-123. https://doi.org/10.1504/IJMDA.2017.10008574

Hallowell. (1999). The human moment at work. Harvard Business Review, 77, 58-66.

Handelsman. (2002). Positive ethics. In C. R. Snyder \& S. J. Lopez (Eds.), Handbook of positive psychology (pp. 731-744). NewYork: Oxford University Press.

Handelsman. (2009). Positive ethics: Themes and variations. In C. R. Snyder \& S. J. Lopez 
(Eds.), Oxford handbook of positive psychology (2nd ed., pp. 105-113). New York: Oxford University Press. https://doi.org/10.1093/oxfordhb/9780195187243.013.0011

Hansen, Alge, Brown, Jackson, \& Dunford. (2013). Ethical leadership: Assessing the value of a multifoci social exchange perspective. Journal of Business Ethics, 115(3), 435-449. https://doi.org/10.1007/s10551-012-1408-1

Hayes. (2013). Introduction to mediation, moderation, and conditional process analysis: A regression-based approach. New York: Guilford Press.

Hayes. (1996). Experiential avoidance and behavioral disorders: A functional dimensional approach to diagnosis and treatment. Journal of Consulting and Clinical Psychology, 64(6), 1152-1168. https://doi.org/10.1037/0022-006X.64.6.1152

Holmvall. (1999b). Distributive, procedural, and interactional justice: Exploring the nomological network of organizational justice constructs. Paper presented at the 14th annual meeting of the Society for Industrial and Organizational Psychology, Atlanta.

Jafari \& Bidarian. (2012). The relationship between organizational justice and organizational citizenship behavior. Procedia-Social and behavioral Sciences. https://doi.org/10.1016/j.sbspro.2012.06.873

Jordan, Brown, Treviño, \& Finkelstein. (2013). Someone to look up to: Executive-follower ethical reasoning and perceptions of ethical leadership. Journal of Management, 39(3), 660-683. https://doi.org/10.1177/0149206311398136

Kacmar, Bachrach, Harris, \& Zivnuska. (2011). Fostering good citizenship through ethical leadership: exploring the moderating role of gender and organizational politics. Journal of Applied Psychology, 96(3), 633-642. https://doi.org/10.1037/a0021872

Kahn. (1998). Relational systems at work. In B. M. Staw \& L. L. Cummings (Eds.), Research in organizational behavior (pp. 39-76). London: Elsevier Science/JAI Press.

Kalshoven, Den Hartog \& De Hoogh. (2011a). Ethical leader behavior and big five factors of personality. Journal of Business Ethics, 100(2), 349-366. https://doi.org/10.1007/s10551-010-0685-9

Kalshoven, Den Hartog, \& De Hoogh. (2011b). Ethical leadership at work questionnaire (ELW): Development and validation of a multidimensional measure. The Leadership Quarterly, 22(1), 51-69. https://doi.org/10.1016/j.leaqua.2010.12.007

Kalshoven. (2013). Ethical leadership and follower helping and courtesy: Moral awareness and empathic concern as moderators. Applied Psychology, 62(2), 211-235. https://doi.org/10.1111/j.1464-0597.2011.00483.x

Kanov. (2004). Compassion in organizational life. American Behavioral Scientist, 47(6), 808-827. https://doi.org/10.1177/0002764203260211

Kim \& Brymer. (2011). The effects of ethical leadership on manager job satisfaction, commitment, behavioral outcomes, and firm performance. International Journal of 
Hospitality Management, 30(4), 1020-1026. https://doi.org/10.1016/j.ijhm.2011.03.008

Kirkman. (2009). Individual power distance orientation and follower reactions to transformational leaders: A cross-level, crosscultural examination. Academy of Management Journal, 52, 744-764. https://doi.org/10.5465/amj.2009.43669971

Kouzes \& Posner. (2008). The leadership challenge (4th ed.). San Francisco: Jossey-Bass.

Kuvaas \& Buch. (2018). Leader-Member Exchange Relationships and Follower Outcomes: The Mediating Role of Perceiving Goals as Invariable. Human Resource Management, 57(1), 235-248. https://doi.org/10.1002/hrm.21826

Kuvaas \& Dysvik. (2009). Perceived investment in employee development, intrinsic motivation and work performance. Human Resource Management Journal, 19(3), 217-236. https://doi.org/10.1111/j.1748-8583.2009.00103.x

Lee \& Allen. (2002). Organizational citizenship behavior and workplace deviance: The role of affect and cognitions. Journal of Applied Psychology, 87, 131-142. https://doi.org/10.1037/0021-9010.87.1.131

Li, Johnson, \& Wu. (2012). Moral leadership and psychological empowerment in China. Journal of Managerial Psychology, 27(1), 90-108. https://doi.org/10.1108/02683941211193875

Lilius. (2011). Compassion revealed: What we know about compassion at work (and where we need to know more). In K. Cameron \& G. Spreitzer (Eds.), Handbook of positive organizational scholarship (pp. 273-287). New York: Oxford University Press.

Loi. (2012). Coping with job insecurity: The role of procedural justice, ethical leadership and power distance orientation. Journal of Business Ethics, 108(3), 361-372. https://doi.org/10.1007/s10551-011-1095-3

Lord. (2001). Contextual constraints on prototype generation and their multilevel consequences for leadership perceptions. The Leadership Quarterly, 12, 311-338. https://doi.org/10.1016/S1048-9843(01)00081-9

Masterson. (2000). Integrating justice and social exchange: The differing effects of fair procedures and treatment on work relationships. Academy of Management Journal, 67, 738-749. https://doi.org/10.2307/1556364

Masterson, Byrne, \& Mao (2005). Interpersonal and informational justice: Identifying the differential antecedents of interactional justice behaviors.

Shrout \& Bolger. (2002). Mediation in experimental and nonexperimental studies: New procedures and recommendations. Psychological Methods, 7(4), 422. https://doi.org/10.1037/1082-989X.7.4.422

Skarlicki, \& K. van den Bos (Eds.). What motivates fairness in organizations? (pp. 79-103). Greenwich, CT: Information Age Publishing. 
Mayer, Aquino, Greenbaum, \& Kuenzi. (2012). Who displays ethical leadership, and why does it matter? An examination of antecedents and consequences of ethical leadership. Academy of management Journal, 55(1), 151-171. https://doi.org/10.5465/amj.2008.0276

Mayer, Kuenzi, \& Greenbaum. (2010). Examining the link between ethical leadership and employee misconduct: The mediating role of ethical climate. Journal of Business Ethics, 95, 7-16. https://doi.org/10.1007/s10551-011-0794-0

Mayer, Kuenzi, Greenbaum, Bardes, \& Salvador. (2009). How low does ethical leadership flow? Test of a trickle-down model. Organizational Behavior \& Human Decision Processes, 108, 1-13. https://doi.org/10.1016/j.obhdp.2008.04.002

Messner \& Rosenfeld. (2001). Crime and the American dream. Belmont, CA: Wadsworth.

Mo \& Shi. (2017). Linking Ethical Leadership to Employees' Organizational Citizenship Behavior: Testing the Multilevel Mediation Role of Organizational Concern. Journal of Business Ethics, 141(1), 151-162. https://doi.org/10.1007/s10551-015-2734-x

Mo et al. (2012). Look up, look around: Is there anything different about team-level OCB in China? Journal of Management \& Organization, 18, 833-844. https://doi.org/10.1017/S1833367200000468

Moorman \& Byrne. (2005). What is the role of justice in promoting organizational citizenship behavior? In J. Greenberg \& J. A. Colquitt (Eds.), Handbook of organizational justice: Fundamental questions about fairness in the workplace (pp. 355-382). Mahwah, NJ: Lawrence Erlbaum Associates

Moorman. (1991). The relationship between organizational justice and organizational citizenship behavior: Do fairness perceptions influence employee citizenship? Journal of Applied Psychology, 76, 845-855. https://doi.org/10.1037/0021-9010.76.6.845

Namoga. (2017). Corporate governance and board performance: Empirical evidence from Pacific Island countries. Cambridge Scholars Publishing.

Neff. (2003). Self-compassion: An alternative conceptualization of a healthy attitude toward oneself. Self and Identity, 2(2), 85-101. https://doi.org/10.1080/15298860309032

Neff. (2007). Self-compassion and its link to adaptive psychological functioning. Journal of Research in Personality, 41(1), 139-154. https://doi.org/10.1016/j.jrp.2006.03.004

Nelson. (2014). The Role of Leader Communication Patterns, LMX, and Interactional Justice in Employee Emotional Exhaustion and Outcomes.

Neubert, Carlson, Kacmar, Roberts, \& Chonko. (2009). The virtuous influence of ethical leadership behavior: Evidence from the field. Journal of Business Ethics, 90(2), 157-170. https://doi.org/10.1007/s10551-009-0037-9

Niehoff \& Moorman. (1993). Justice as a Mediator of the Relationship between Methods of Monitoring and Organizational Citizenship Behavior. The Academy of Management Journal. https://doi.org/10.2307/256591 


\section{Macrothink}

Global Journal of Educational Studies ISSN 2377-3936 2021, Vol. 7, No. 2

Nolen-Hoeksema. (1991). Responses to depression and their effects on the duration of depressive episodes. Journal of Abnormal Psychology, 100(4), 569-582. https://doi.org/10.1037/0021-843X.100.4.569

Northouse. (2010). Leadership: Theory and practice (5th ed.). Thousand Oaks, CA: Sage Publications Inc.

Opotow. (1990). Moral exclusion and injustice: An introduction. Journal of Social Issues, 46(1), 1-20. https://doi.org/10.1111/j.1540-4560.1990.tb00268.x

Organ. (1997). Organizational citizenship behavior: It's construct cleanup time. Human Performance, 10(2), 85-97. https://doi.org/10.1207/s15327043hup1002_2

Organ. (1988). Organizational citizenship behavior: The good soldier syndrome. Lexington: Lexington Books.

Oshio \& Kobayashi. (2009). Income inequality, area-level poverty, perceived aversion to inequality, and self-rated health in Japan. Social Science \& Medicine, 69(3), 317-326. https://doi.org/10.1016/j.socscimed.2009.06.004

Parker \& Axtell. (2001). Seeing another viewpoint: Antecedents and outcomes of employee perspective taking. Academy of Management Journal, 44(6), 1085-1100. https://doi.org/10.5465/3069390

Passas. (1995). Continuities in the anomie tradition. In F. Adler \& W. Laufer (Eds.), The legacy of anomie theory. Advances in Criminological Theory, 6, 91-112. New Brunswick, NJ: Transaction Publishers. https://doi.org/10.1201/9780429335945-5

Piccolo \& Colquitt. (2006). Transformational leadership and job behaviors: The mediating role of core job characteristics. Academy of Management Journal, 49(2), 327-340. https://doi.org/10.5465/amj.2006.20786079

Piccolo. (2010). The relationship between ethical leadership and core job characteristics. Journal of Organizational Behavior, 31, 259-278. https://doi.org/10.1002/job.627

Podsakoff. (1997). Organizational citizenship behavior and the quantity and quality of work team performance. Journal of Applied Psychology, 82, 262-270. https://doi.org/10.1037/0021-9010.82.2.262

Podsakoff. (2000). Organizational citizenship behaviors: A critical review of the theoretical and empirical literature and suggestions for future research. Journal of Management, 26, 513-563. https://doi.org/10.1177/014920630002600307

Ponnu \& Tennakoon. (2009). The association between ethical leadership and employee outcomes-The Malaysian case. Electronic Journal of Business Ethics and Organization Studies, 14(1), 21-32.

Rinpoche. (1992). The Tibetan Book of Living and Dying. In P. Gaffney, and A. Harvey (Eds.). San Francisco: HarperOne. 


\section{Mll Macrothink}

Global Journal of Educational Studies

ISSN 2377-3936

2021, Vol. 7, No. 2

Robbins \& Judge. (2007). Organizational behavior (12th ed.). Upper Saddle River, NJ: Pearson Education, Inc

Roch \& Shanock. (2006). Organizational justice in an exchange framework: Clarifying organizational justice distinctions. Journal of Management, 32, 299-322. https://doi.org/10.1177/0149206305280115

Rubin, D., \& Brown, M. E. (2010). Do ethical leaders get ahead? Exploring ethical leadership and promotability. Business Ethics Quarterly, 20(2), 215-236. https://doi.org/10.5840/beq201020216

Rupp \& Cropanzano. (2002). The mediating effects of social exchange relationships in predicting workplace outcomes from multifoci organizational justice. Organizational Behavior and Human Decision Processes, 89, 925-946. https://doi.org/10.1016/S0749-5978(02)00036-5

Schaubroeck. (2012). Embedding ethical leadership within and across organization levels. Academy of management Journal, 55(5), 1053-1078. https://doi.org/10.5465/amj.2011.0064

Schminke. (2002). Leadership and ethics in work groups. Group and Organization Management, 27, 272-293. https://doi.org/10.1177/10501102027002006

Schyns. (2001). Income and satisfaction in Russia. Journal of Happiness Studies, 2(2), 173-204. https://doi.org/10.1023/A:1011564631319

Sekerka. (2010). Getting curious about ethics: Cultivating intrinsic motivation toward moral awareness in the workplace. Australian Association for Professional and Applied Ethics National Conference (June 10th), Conference Proceedings, University of Sydney, Sydney, Australia, 6/10

Simpson. (2014). Normal compassion: A framework for compassionate decision making. Journal of Business Ethics, 119(4), 473-491. https://doi.org/10.1007/s10551-013-1831-y

Stansbury \& Sonenshein. (2012). Positive business ethics: Grounding and elaborating a theory of good works. In K. S. Cameron \& G. M. Spreitzer (Eds.), Handbook of positive organizational scholarship (pp. 340-352). Oxford: Oxford University Press.

Stringer. (2002). Leadership and organizational climate. Upper Saddle River, NJ: Pearson Education Inc.

Tang. (2015). Theory of justice, ocb and individualism. Springer Science .

Thau \& Mitchell. (2010). Self-gain or self-regulation impairment? Tests of competing explanations of the supervisor abuse and employee deviance relationship through perceptions of distributive justice. Journal of applied psychology, 95(6), 1009. https://doi.org/10.1037/a0020540

Tirch, D. D. (2010). Mindfulness as a context for the cultivation of compassion. International Journal of Cognitive Therapy, 3(2), 113-123. https://doi.org/10.1521/ijct.2010.3.2.113 


\section{Macrothink}

Global Journal of Educational Studies

ISSN 2377-3936

2021, Vol. 7, No. 2

Thomas, Schermerhorn, Jr., \& Dienhart. (2004). Strategic leadership of ethical behavior in business. Academy of Management Executive, 18, 56-66. https://doi.org/10.5465/ame.2004.13837425

Treviño. (2006). Behavioral ethics in organizations: A review. Journal of Management, 32, 951-990. https://doi.org/10.1177/0149206306294258

Treviño. (2000). Moral person and moral manager: How executives develop a reputation for ethical leadership. California Management Review, 42, 128-142. https://doi.org/10.2307/41166057

Trevino \& Brown. (2004). Managing to be ethical: Debunking five business ethics myths. Academy of Management Executive, 18, 69-81. https://doi.org/10.5465/ame.2004.13837400

Treviño, Brown, \& Hartman. (2003). A qualitative investigation of perceived executive ethical leadership: Perceptions from inside and outside the executive suite. Human Relations, 5-37. https://doi.org/10.1177/0018726703056001448

Umphress, Bingham, \& Mitchell. (2010). Unethical behavior in the name of the company: the moderating effect of organizational identification and positive reciprocity beliefs on unethical pro-organizational behavior. Journal of applied psychology, 95(4), 769. https://doi.org/10.1037/a0019214

Van Dyne. (1995). Extra-role behaviors: in pursuit of construct and definitional clarity (a bridge over muddied waters). Research in Organizational Behavior, 17, 215-285.

Verbos. (2007). The positive ethical organization: Enacting a living code of ethics and ethical organizational identity. Journal of Business Ethics, 76(1), 17-33. https://doi.org/10.1007/s10551-006-9275-2

Vianello. (2010). Elevation at work: The effects of leaders' moral excellence. The Journal of Positive Psychology, 5(5), 390-411. https://doi.org/10.1080/17439760.2010.516764

Victor \& Cullen. (1987). A theory and measure of ethical climate in organizations. Research in Corporate Social Performance and Policy, 9(1), 51-71.

Waddock. (2001). Integrity and mindfulness: Foundations of corporate citizenship. Journal of Corporate Citizenship, 1(1), 25-37. https://doi.org/10.9774/GLEAF.4700.2001.sp.00006

Walumbwa \& Schaubroeck (2009). Leader personality traits and employee voice behavior: Mediating roles of ethical leadership and work group psychological safety. Journal of Applied Psychology, 94(5), 1275. https://doi.org/10.1037/a0015848

Walumbwa. (2011). Linking ethical leadership to employee performance: The roles of leadermember exchange, self-efficacy, and organizational identification. Organizational Behavior and Human Decision Processes, 115(2), 204-213. https://doi.org/10.1016/j.obhdp.2010.11.002

Walumbwa, Hartnell, \& Misati. (2017). Does ethical leadership enhance group learning behavior? Examining the mediating influence of group ethical conduct, justice climate, and 
peer justice. Journal of Business Research, 72, 14-23. https://doi.org/10.1016/j.jbusres.2016.11.013

Wang. (2015). Ethical leadership and loyalty to supervisor in china: The roles of interactional justice and collectivistic orientation. Journal of Business Ethics, 1-15. https://doi.org/10.1007/s10551-015-2916-6

Weaver \& Treviño. (1999). Compliance and values oriented ethics programs: Influences on employees' attitudes and behavior. Business Ethics Quarterly, 9, 315-337. https://doi.org/10.2307/3857477

Weaver. (1999). Corporate ethics programs as control systems: Influences of executive commitment and environmental factors. Academy of Management Journal, 42(1), 41-57. https://doi.org/10.2307/256873

Weiss \& Cropanzano. (1996). Affective events theory: A theoretical discussion of the structure, causes, and consequences of affective experiences at work. Research in Organizational Behavior, 18, 1-74.

Williams \& Anderson. (1991). Job satisfaction and organizational commitment as predictors of organizational citizenship and in-role behaviors. Journal of Management, 17, 601-617. https://doi.org/10.1177/014920639101700305

Wispe. (1991). The psychology of sympathy. New York: Plenum. https://doi.org/10.1007/978-1-4757-6779-7

Wu, Neubert, \& Yi. (2007). Transformational leadership, cohesion perceptions, and employee cynicism about organizational change the mediating role of justice perceptions. The Journal of Applied Behavioral Science, 43(3), 327-351. https://doi.org/10.1177/0021886307302097

$\mathrm{Xu}$, A. et. al. (2016). Ethical leadership behavior and employee justice perceptions: The mediating role of trust in organization. Journal of Business Ethics, 134(3), 493-504. https://doi.org/10.1007/s10551-014-2457-4

Yukl. (2002). Leadership in organizations (5th ed.). Upper Saddle River, NJ: PrenticeHall, Inc.

Zheng. (2015). Effects of ethical leadership on emotional exhaustion in high moral intensity $\begin{array}{llll}\text { situations. The } \quad \text { Teadership } & \text { 26urterly, }\end{array}$ https://doi.org/10.1016/j.leaqua.2015.01.006

Zhu. (2004). The impact of ethical leadership behavior on employee outcomes: The roles of psychological empowerment and authenticity. Journal of Leadership and Organizational Studies, 11(1), 16-26. https://doi.org/10.1177/107179190401100104

Zhu, Treviño, \& Zheng (2016). Ethical Leaders and Their Followers: The Transmission of Moral Identity and Moral Attentiveness. Business Ethics Quarterly, 26(01), 95-115. https://doi.org/10.1017/beq.2016.11

Zoghbi-Manrique-de-Lara \& Guerra-Baez (2016). Exploring the influence of ethical climate 


\section{Macrothink}

Global Journal of Educational Studies

ISSN 2377-3936 2021, Vol. 7, No. 2

on employee compassion in the hospitality industry. Journal of Business Ethics, 133(3), 605-617. https://doi.org/10.1007/s10551-014-2415-1

Zoghbi-Manrique-de-Lara \& Sua'rez-Acosta (2014). Employees' reactions to peers' unfair treatment by supervisors: The role of ethical leadership. Journal of Business Ethics, 122(4), 537-549. https://doi.org/10.1007/s10551-013-1778-z

Zoghbi-Manrique-de-Lara \& Viera-Armas (2019). Does ethical leadership motivate followers to participate in delivering compassion?. Journal of Business Ethics, 154(1), 195-210. https://doi.org/10.1007/s10551-017-3454-1

Zoghbi-Manrique-de-Lara \& Suarez-Acosta (2013). Employees' reactions to peers' unfair treatment by supervisors: The role of ethical leadership. Journal of Business Ethics.

\section{Copyright Disclaimer}

Copyright for this article is retained by the author(s), with first publication rights granted to the journal.

This is an open-access article distributed under the terms and conditions of the Creative Commons Attribution license (http://creativecommons.org/licenses/by/3.0/). 